\title{
LEVEL II SCOUR ANALYSIS FOR BRIDGE 34 (JAMATH00080034) on TOWN HIGHWAY 8, crossing the WINHALL RIVER, JAMAICA, VERMONT
}

Open-File Report 98-539

Prepared in cooperation with

VERMONT AGENCY OF TRANSPORTATION

and

FEDERAL HIGHWAY ADMINISTRATION

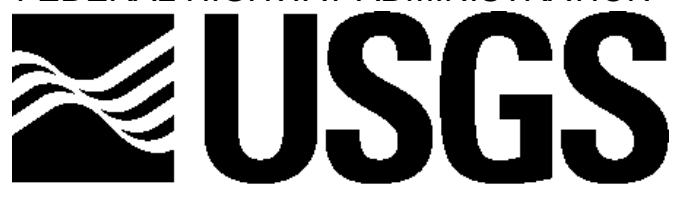

science for a changing world

U.S. Department of the Interior

U.S. Geological Survey 


\section{LEVEL II SCOUR ANALYSIS FOR BRIDGE 34 (JAMATH00080034) on TOWN HIGHWAY 8, crossing the WINHALL RIVER, \\ JAMAICA, VERMONT}

By MICHAEL A. IVANOFF AND LAURA MEDALIE

U.S. Geological Survey Open-File Report 98-539

Prepared in cooperation with

VERMONT AGENCY OF TRANSPORTATION and

FEDERAL HIGHWAY ADMINISTRATION 


\title{
U.S. DEPARTMENT OF THE INTERIOR BRUCE BABBITT, Secretary
}

\author{
U.S. GEOLOGICAL SURVEY
}

Thomas J. Casadevall, Acting Director

For additional information write to:

District Chief

U.S. Geological Survey 361 Commerce Way

Pembroke, NH 03275-3718
Copies of this report may be purchased from:

U.S. Geological Survey

Branch of Information Services

Open-File Reports Unit

Box 25286

Denver, CO 80225-0286 


\section{CONTENTS}

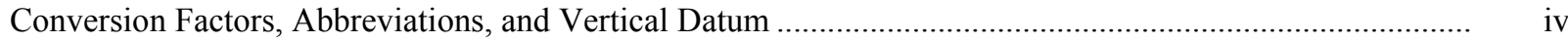

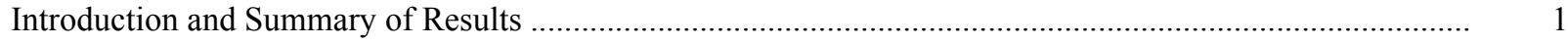

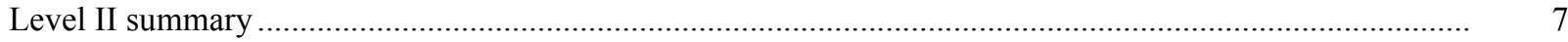

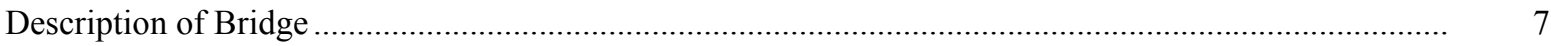

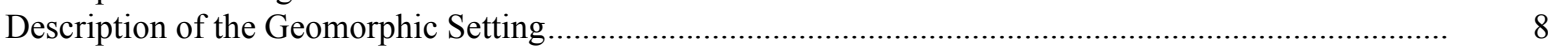

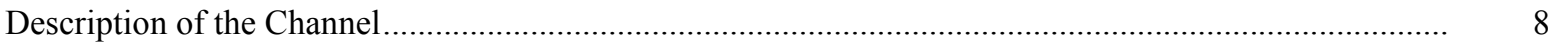

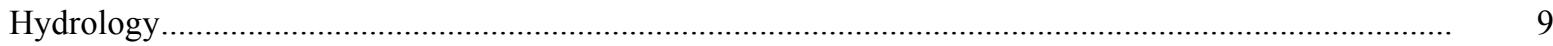

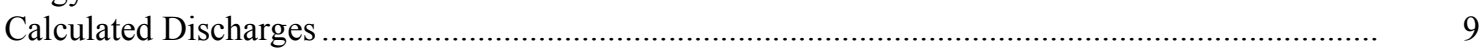

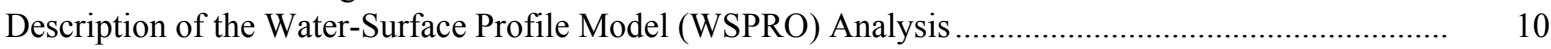

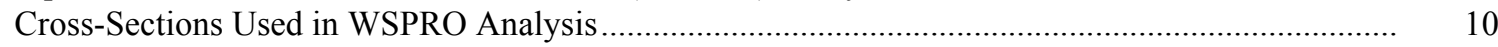

Data and Assumptions Used in WSPRO Model ........................................................................ 11

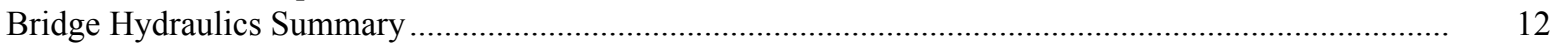

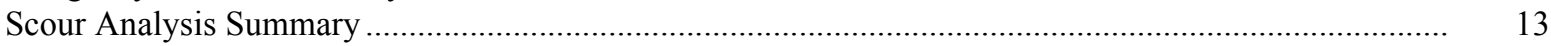

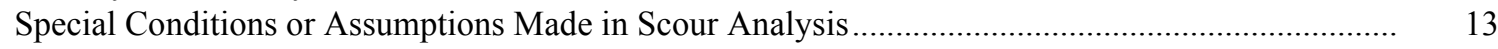

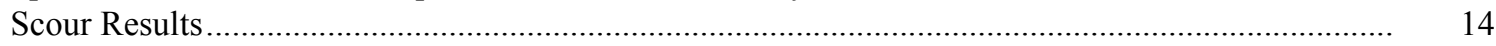

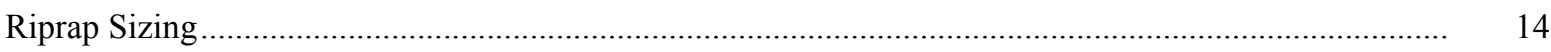

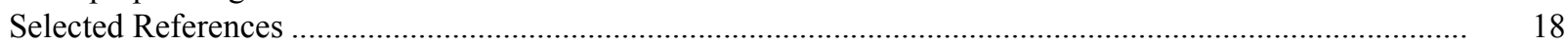

Appendices:

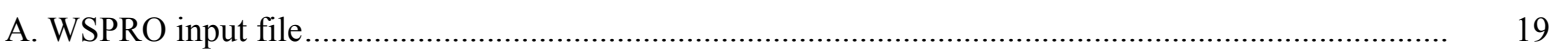

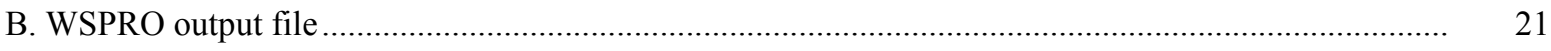

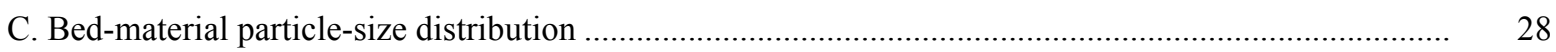

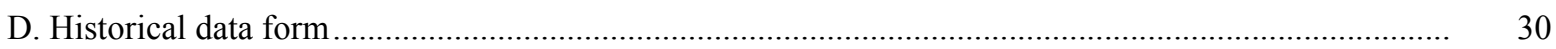

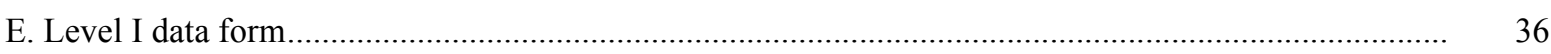

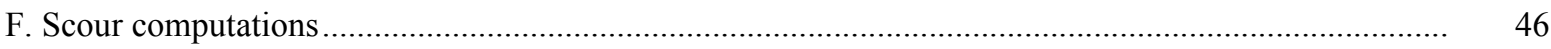

\section{FIGURES}

1. Map showing location of study area on USGS 1:24,000 scale map

2. Map showing location of study area on Vermont Agency of Transportation town highway map

3. Structure JAMATH00080034 viewed from upstream (August 7, 1996).

4. Downstream channel viewed from structure JAMATH00080034 (August 7, 1996)

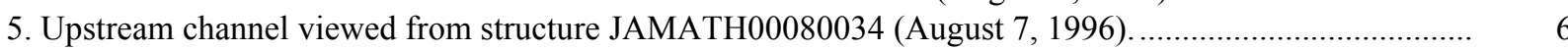

6. Structure JAMATH00080034 viewed from downstream (August 7, 1996).

7. Water-surface profiles for the 100- and 500-year discharges at structure JAMATH00080034 on Town Highway 8, crossing the Winhall River, Jamaica, Vermont.

8. Scour elevations for the 100- and 500-year discharges at structure

JAMATH00080034 on Town Highway 8, crossing the Winhall River, Jamaica, Vermont.

\section{TABLES}

1. Remaining footing/pile depth at abutments for the 100-year discharge at structure

JAMATH00080034 on Town Highway 8, crossing the Winhall River,

Jamaica, Vermont...

2. Remaining footing/pile depth at abutments for the 500-year discharge at structure

JAMATH00080034 on Town Highway 8, crossing the Winhall River,

Jamaica, Vermont. 


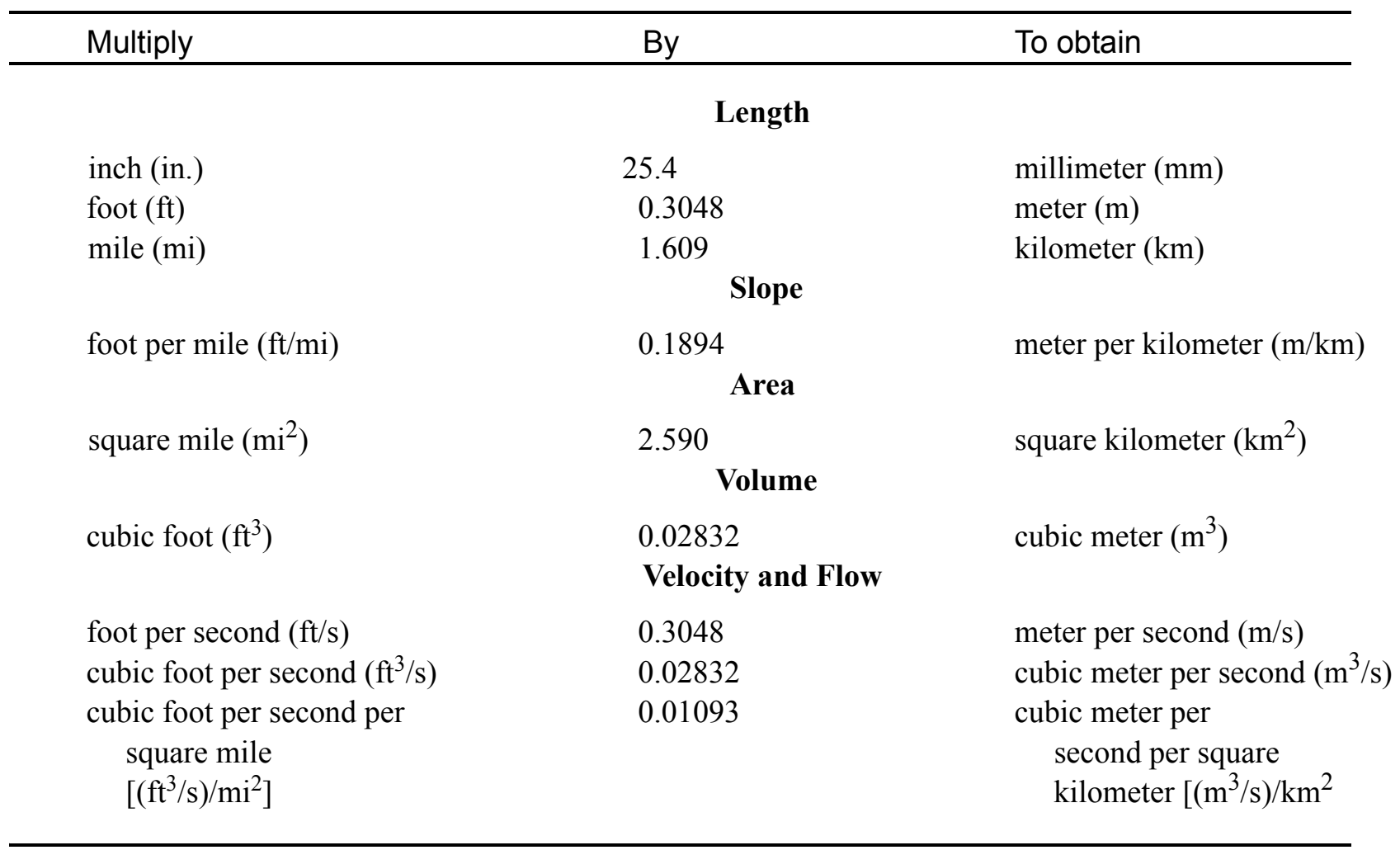

\section{OTHER ABBREVIATIONS}

$\begin{array}{lrlr}\mathrm{BF} & \text { bank full } & \text { LWW } & \text { left wingwall } \\ \mathrm{cfs} & \text { cubic feet per second } & \text { Max } & \text { maximum } \\ \mathrm{D}_{50} & \text { median diameter of bed material } & \text { MC } & \text { main channel } \\ \mathrm{DS} & \text { downstream } & \text { RAB } & \text { right abutment } \\ \mathrm{elev} & \text { elevation } & \text { RABUT } & \text { face of right abutment } \\ \mathrm{f} / \mathrm{p} & \text { flood plain } & \text { RB } & \text { right bank } \\ \mathrm{ft} & \text { square feet } & \text { ROB } & \text { right overbank } \\ \mathrm{ft} / \mathrm{ft} & \text { feet per foot } & \text { RWW } & \text { right wingwall } \\ \mathrm{FEMA} & \text { Federal Emergency Management Agency } & \text { TH } & \text { town highway } \\ \mathrm{FHWA} & \text { Federal Highway Administration } & \text { UB } & \text { under bridge } \\ \mathrm{JCT} & \text { junction } & \text { US } & \text { upstream } \\ \text { LAB } & \text { left abutment } & \text { USGS } & \text { United States Geological Survey } \\ \text { LABUT } & \text { face of left abutment } & \text { VTAOT } & \text { Vermont Agency of Transportation } \\ \text { LB } & \text { left bank } & \text { WSPRO } & \text { water-surface profile model } \\ \text { LOB } & \text { left overbank } & \text { yr } & \text { year }\end{array}$

In this report, the words "right" and "left" refer to directions that would be reported by an observer facing downstream. Sea level: In this report, "sea level" refers to the National Geodetic Vertical Datum of 1929-- a geodetic datum derived from a general adjustment of the first-order level nets of the United States and Canada, formerly called Sea Level Datum of 1929.

In the appendices, the above abbreviations may be combined. For example, USLB would represent upstream left bank. 


\title{
LEVEL II SCOUR ANALYSIS FOR BRIDGE 34 (JAMATH00080034) ON TOWN HIGHWAY 8, CROSSING THE WINHALL RIVER, JAMAICA, VERMONT
}

\author{
By Michael A. Ivanoff and Laura Medalie
}

\section{INTRODUCTION AND SUMMARY OF RESULTS}

This report provides the results of a detailed Level II analysis of scour potential at structure JAMATH00080034 on Town Highway 8 crossing the Winhall River, Jamaica, Vermont (figures 1-8). A Level II study is a basic engineering analysis of the site, including a quantitative analysis of stream stability and scour (FHWA, 1993). Results of a Level I scour investigation also are included in appendix E of this report. A Level I investigation provides a qualitative geomorphic characterization of the study site. Information on the bridge, gleaned from Vermont Agency of Transportation (VTAOT) files, was compiled prior to conducting Level I and Level II analyses and is found in appendix D.

The site is in the Green Mountain section of the New England physiographic province in southern Vermont. The 45.1- $\mathrm{mi}^{2}$ drainage area is in a predominantly rural and forested basin. In the vicinity of the study site, along the right bank, the surface cover is pasture while the immediate banks have dense woody vegetation and along the left bank the surface cover is forest.

In the study area, the Winhall River has an incised, sinuous channel with a slope of approximately $0.02 \mathrm{ft} / \mathrm{ft}$, an average channel top width of $109 \mathrm{ft}$ and an average bank height of $4 \mathrm{ft}$. The channel bed material ranges from gravel to boulder with a median grain size $\left(\mathrm{D}_{50}\right)$ of $105 \mathrm{~mm}(0.346 \mathrm{ft})$. The geomorphic assessment at the time of the Level I and Level II site visit on August 7, 1996, indicated that the reach was laterally unstable with moderate to heavy fluvial erosion upstream.

The Town Highway 8 crossing of the Winhall River is a 74-ft-long, one-lane bridge consisting of one 70-foot steel-beam span (Vermont Agency of Transportation, written communication, April 6, 1995). The opening length of the structure parallel to the bridge face is $65.5 \mathrm{ft}$. The bridge is supported by vertical, concrete abutments with wingwalls. The channel is skewed zero degrees to the opening and the opening-skew-to-roadway is also zero degrees. 
A scour hole $2 \mathrm{ft}$ deeper than the mean thalweg depth was observed in the channel under the bridge during the Level I assessment. The scour protection measures at the site included type-2 stone fill (less than 36 inches diameter) along the upstream left and right wingwalls, the upstream end of the right abutment, the upstream right bank, and the downstream left bank; type-3 stone fill (less than 48 inches diameter) along the downstream left wingwall and upstream left bank; and type-4 stone fill (less than 60 inches diameter) along the left abutment. Additional details describing conditions at the site are included in the Level II Summary and appendices D and E.

Scour depths and recommended rock rip-rap sizes were computed using the general guidelines described in Hydraulic Engineering Circular 18 (Richardson and Davis, 1995) for the 100- and 500-year discharges. In addition, the incipient roadway-overtopping discharge was determined and analyzed as another potential worst-case scour scenario. Total scour at a highway crossing is comprised of three components: 1) long-term streambed degradation; 2) contraction scour (due to accelerated flow caused by a reduction in flow area at a bridge) and; 3 ) local scour (caused by accelerated flow around piers and abutments). Total scour is the sum of the three components. Equations are available to compute depths for contraction and local scour and a summary of the results of these computations follows.

Contraction scour for all modelled flows ranged from 0.3 to $0.6 \mathrm{ft}$. The worst-case contraction scour occurred at the incipient roadway-overtopping discharge. Abutment scour ranged from 8.6 to $16.5 \mathrm{ft}$. The worst-case abutment scour occurred at the 500 -year discharge. Additional information on scour depths and depths to armoring are included in the section titled "Scour Results". Scoured-streambed elevations, based on the calculated scour depths, are presented in tables 1 and 2. A cross-section of the scour computed at the bridge is presented in figure 8 . Scour depths were calculated assuming an infinite depth of erosive material and a homogeneous particle-size distribution.

It is generally accepted that the Froehlich equation (abutment scour) gives "excessively conservative estimates of scour depths" (Richardson and Davis, 1995, p. 46). Usually, computed scour depths are evaluated in combination with other information including (but not limited to) historical performance during flood events, the geomorphic stability assessment, existing scour protection measures, and the results of the hydraulic analyses. Therefore, scour depths adopted by VTAOT may differ from the computed values documented herein. 


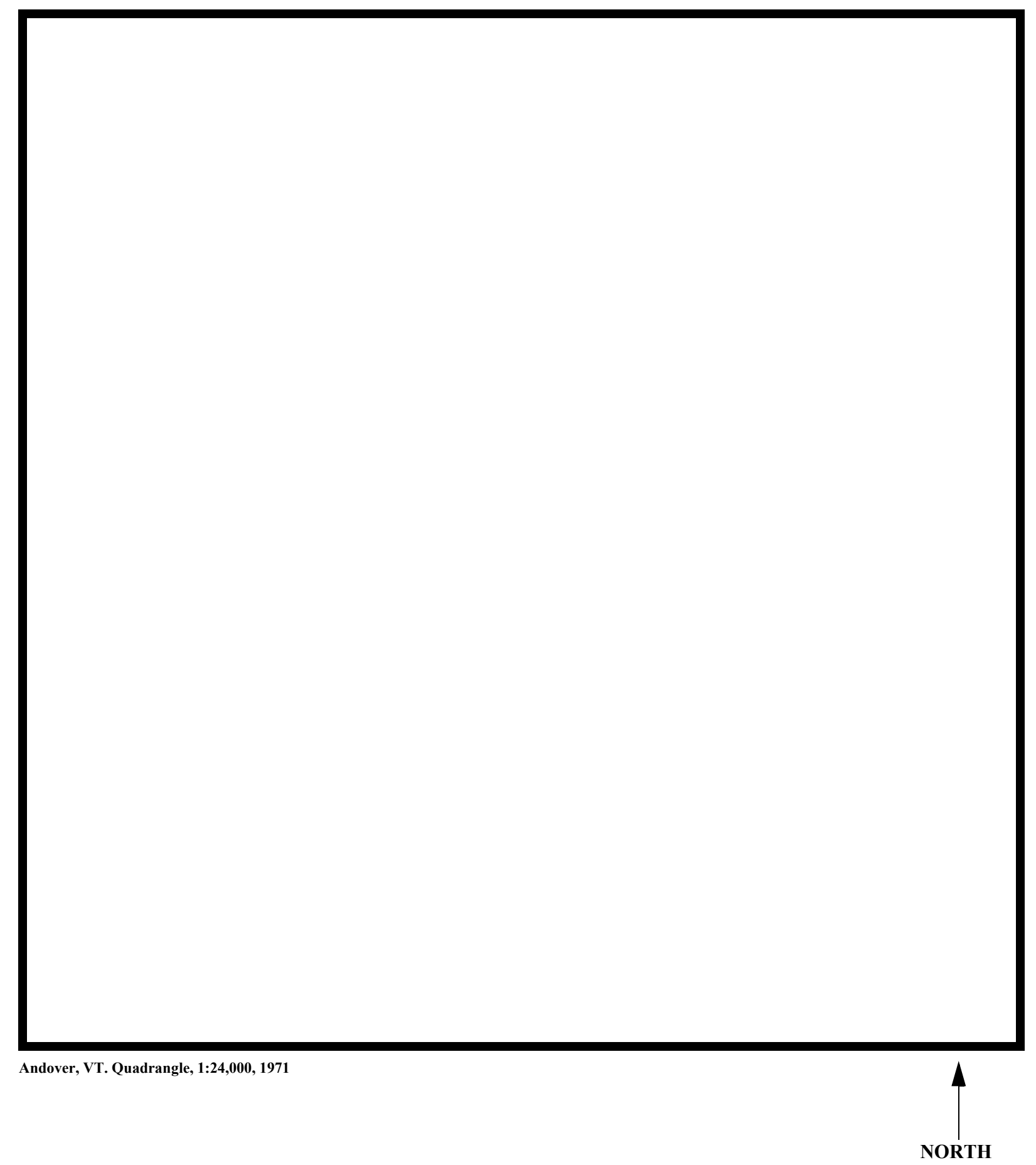

Figure 1. Location of study area on USGS 1:24,000 scale map. 
Figure 2. Location of study area on Vermont Agency of Transportation town highway map. 

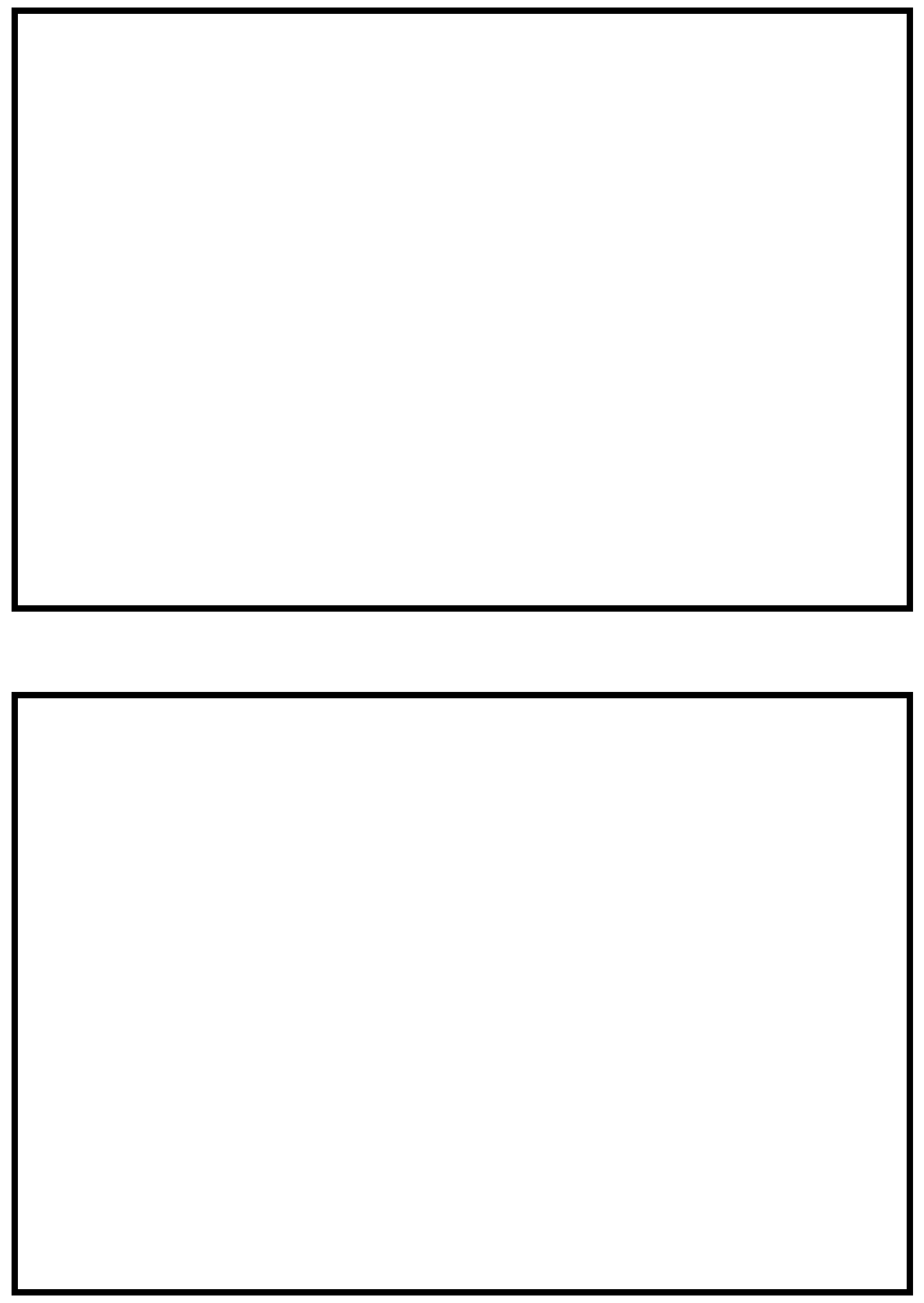

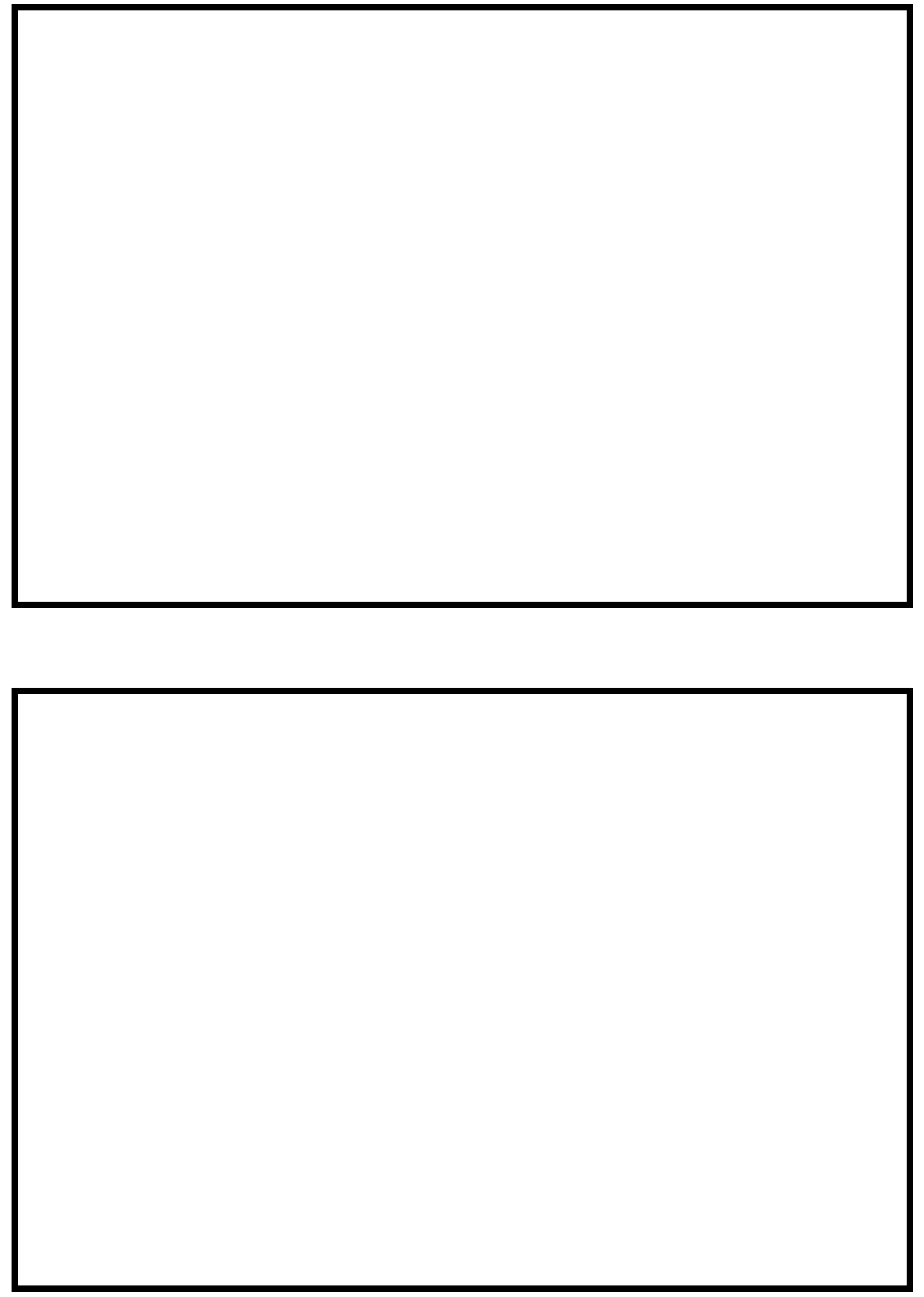


\section{LEVEL II SUMMARY}

\begin{tabular}{llllll} 
Structure Number & JAMATH00080034 & & \multicolumn{3}{l}{ Winhall River } \\
Stream & & & \\
County & Windham & Road & TH 34 & District &
\end{tabular}

\section{Description of Bridge}

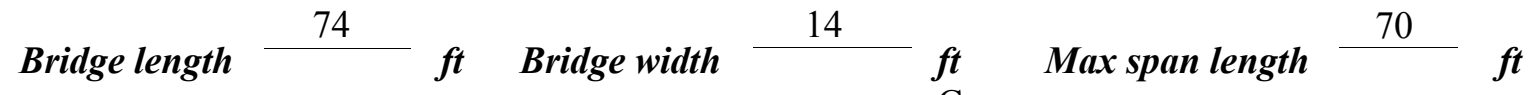
Alignment of bridge to road (on curve or straight)

\section{Abutment type} Vertical, concrete

Stone fill on abutment?

$$
\text { Yes }
$$

\section{Embankment type} Curve

Drto af incnortinn. Type-2, along the upstream left and right wingwalls and at the upstream end of the right abutment. Type-4, along the entire base of the left abutment. Type-3, along the downstream left wingwall.

Abutments and wingwalls are concrete. There is a two

ft deep scour hole in the channel in front of the left abutment.

\section{No}

Is bridge skewed to flood flow according to Yes ' survey?

Angle

Debris accumulation on bridge at time of Level I or Level II site visit:

\begin{tabular}{|c|c|c|c|}
\hline & $\begin{array}{c}\text { Date of insnortion } \\
8 / 7 / 96 \\
\end{array}$ & $\begin{array}{l}\text { Percent of alsmual } \\
\text { bloeked inortzontatly }\end{array}$ & $\begin{array}{l}\text { Percent of allol } \\
\text { blocked verticatty }\end{array}$ \\
\hline Level I & $8 / 7 / 96$ & 0 & 0 \\
\hline & Moderate. & & \\
\hline
\end{tabular}

\section{Potential for debris}

None were observed on 8/7/96.

Doscriho anv, fonturos noar ar at tho hridoo that mav, affort flow, (includo ahsorvation dato). 


\section{Description of the Geomorphic Setting}

General topography The channel is located within a moderate relief valley.

Geomorphic conditions at bridge site: downstream (DS), upstream (US)

Date of inspection $\quad 8 / 7 / 96$

DS left: $\quad$ Steep valley wall

DS right: $\quad$ Moderately sloped channel bank to a narrow flood plain

US left: $\quad$ Steep valley wall

US right: $\quad$ Moderately sloped channel bank to a narrow flood plain

\section{Description of the Channel}

\begin{tabular}{|c|c|c|c|}
\hline \multirow[b]{2}{*}{ Average top width } & 109 & \multirow[b]{2}{*}{ Average depth } & \multirow[b]{2}{*}{ Sand/Gravel ${ }^{\boldsymbol{f t}}$} \\
\hline & $\stackrel{\boldsymbol{f t}}{\text { Gravel / Cobbles }}$ & & \\
\hline Predominant bed mo & & Bank material & Sinuous but stable \\
\hline
\end{tabular}

with semi-allúvial channel boundaries and a narrow flood plain."

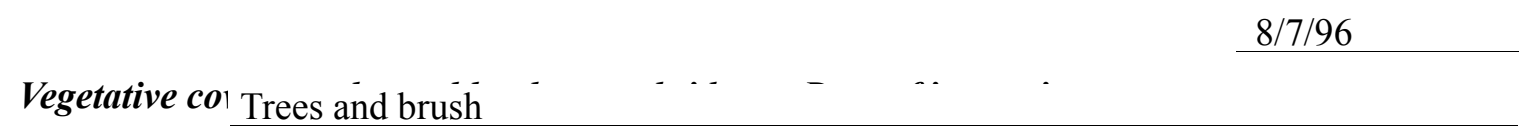

DS left: $\quad$ Trees and brush on the immediate bank with short grass on the flood plain

DS right: $\quad$ Trees and brush

US left: $\quad$ Trees and brush on the immediate bank with short grass on the flood plain

US right: $\quad$ No

Do banks appear stable? There is moderate to heavy fluvial erosion unstream with light fluvial erosion downstream. There are extensively damaged cut-banks upstream and downstream.
date of observatton.

None were observed on 8/7/96.

Describe any obstructions in channel and date of observation. 


\title{
Hydrology
}

Drainage area $\quad \frac{45.1}{\boldsymbol{m i}^{2}}$

Percentage of drainage area in physiographic provinces: (approximate)

Physiographic province/section

New England/Green Mountain
Percent of drainage area 100

\begin{abstract}
Is drainage area considered rural or urban?
Rural urbanization: None

Describe any significant
\end{abstract}

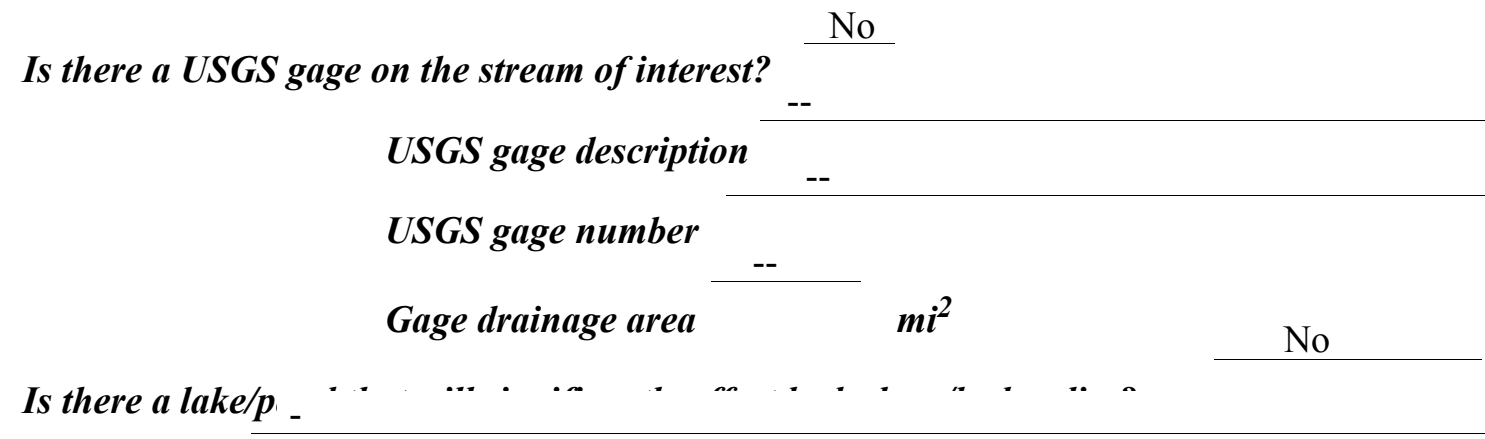

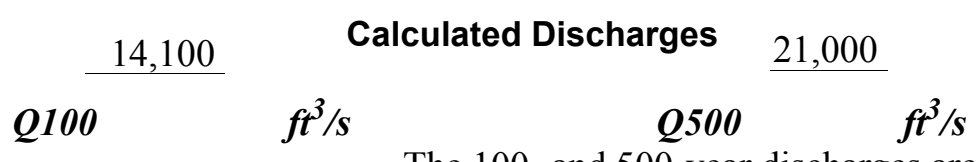

The 100- and 500-year discharges are based on a

drainage area relationship [(45.1/30.5/exp 0.67] with flood frequency estimates available from the VTAOT database (written communication, May 1995) for bridge number 40 in Jamaica. Bridge number 40 crosses the Winhall River upstream of this site and has a drainage area of 30.5 square miles. These area adjusted values are within a range defined by flood frequency curves derived from several empirical methods (Benson, 1962; Johnson and Tasker, 1974; FHWA, 1983; Potter, $1957 \mathrm{a} \& \mathrm{~b} ;$ Talbot, 1887). Each curve was extended graphically to the 500-year event. 


\section{Description of the Water-Surface Profile Model (WSPRO) Analysis}

Datum for WSPRO analysis (USGS survey, sea level, VTAOT plans)

USGS survey

Datum tie between USGS survey and VTAOT plans

None. Add $562 \mathrm{ft}$ to the USGS

arbitrary survey datum to obtain the National Geodetic Vertical Datum of 1929.

Description of reference marks used to determine USGS datum. $\quad$ RM1 is a chiseled X on

top of the downstream end of the right abutment (elev. $498.00 \mathrm{ft}$, arbitrary survey datum). RM2

is a chiseled X on top of the downstream end of the downstream left wingwall (elev. $493.92 \mathrm{ft}$,

arbitrary survey datum).

Cross-Sections Used in WSPRO Analysis

\begin{tabular}{cccl}
\hline${ }^{1}$ Cross-section & $\begin{array}{c}\text { Section } \\
\text { Reference } \\
\text { Distance } \\
\text { (SRD) } \text { in feet }\end{array}$ & $\begin{array}{c}{ }^{2} \text { Cross-section } \\
\text { development }\end{array}$ & \multicolumn{1}{c}{ Comments } \\
\hline EXITX & -74 & 1 & $\begin{array}{l}\text { Exit section } \\
\text { Downstream Full-valley } \\
\text { section (Templated from } \\
\text { EXITX) }\end{array}$ \\
FULLV & 0 & 2 & $\begin{array}{l}\text { Bridge section } \\
\text { Road Grade section }\end{array}$ \\
RDWAY & 0 & 1 & $\begin{array}{l}\text { Modelled Approach sec- } \\
\text { tion (Templated from } \\
\text { APTEMO }\end{array}$ \\
& 93 & 1 & $\begin{array}{l}\text { APTEM) } \\
\text { Approach section as sur- } \\
\text { veyed (Used as a tem- } \\
\text { plate) }\end{array}$ \\
\hline
\end{tabular}

${ }^{1}$ For location of cross-sections see plan-view sketch included with Level I field form, Appendix E.

For more detail on how cross-sections were developed see WSPRO input file. 


\section{Data and Assumptions Used in WSPRO Model}

Hydraulic analyses of the reach were done by use of the Federal Highway Administration's WSPRO step-backwater computer program (Shearman and others, 1986, and Shearman, 1990). The analyses reported herein reflect conditions existing at the site at the time of the study. Furthermore, in the development of the model it was necessary to assume no accumulation of debris or ice at the site. Results of the hydraulic model are presented in the Bridge Hydraulic Summary, appendix B, and figure 7.

Channel roughness factors (Manning's " $n$ ") used in the hydraulic model were estimated using field inspections at each cross section following the general guidelines described by Arcement and Schneider (1989). Final adjustments to the values were made during the modelling of the reach. Channel " $n$ " values for the reach ranged from 0.050 to 0.065 , and the overbank "n" value was 0.035 .

Normal depth at the exit section (EXITX) was assumed as the starting water surface. This depth was computed by use of the slope-conveyance method outlined in the user's manual for WSPRO (Shearman, 1990). The slope used was $0.0158 \mathrm{ft} / \mathrm{ft}$, which was estimated from the topographic map (U.S. Geological Survey, 1971).

The surveyed approach section (APTEM) was moved along the approach channel slope $(0.032 \mathrm{ft} / \mathrm{ft})$ to establish the modelled approach section (APPRO), one bridge length upstream of the upstream face as recommended by Shearman and others (1986). This location provides a consistent method for determining scour variables. 


\section{Bridge Hydraulics Summary}

$\begin{array}{llll}\text { Average bridge embankment elevation } & 500.5 & f t \\ \text { Average low steel elevation } & 497.6 & \boldsymbol{f t}\end{array}$

100-year discharge $\quad 14,100 \quad \mathrm{ft}^{3} / \mathrm{s}$

Water-surface elevation in bridge opening $\quad 497.7 \quad f t$

Road overtopping? ___ Yes Discharge over road __ $7,010 \quad \mathrm{ft}^{3} / \mathrm{s}$

Area of flow in bridge opening $\quad 635 \quad \mathrm{ft}^{2}$

Average velocity in bridge opening $11.3 \mathrm{ft} / \mathrm{s}$

$\begin{array}{llll}\text { Maximum WSPRO tube velocity at bridge } & 14.6 \mathrm{ft} / \mathrm{s}\end{array}$

Water-surface elevation at Approach section with bridge 500.9

Water-surface elevation at Approach section without bridge $\quad \overline{498.2}$

Amount of backwater caused by bridge

$2.7 \quad i$

500-year discharge $\quad 21,000 \quad \boldsymbol{f t}^{3} / \mathrm{s}$

Water-surface elevation in bridge opening $\quad 498.0 \mathrm{ft}$

Road overtopping? ___ Yes Discharge over road __ 13,400 $\boldsymbol{f t}^{3} / \mathbf{s}$

Area of flow in bridge opening $\quad 638 \quad \mathrm{ft}^{2}$

Average velocity in bridge opening $11.5 \mathrm{ft} / \mathrm{s}$

Maximum WSPRO tube velocity at bridge 13.7 's

Water-surface elevation at Approach section with bridge 502.5

Water-surface elevation at Approach section without bridge $\quad 499.5$

Amount of backwater caused by bridge $\quad 3.0$.t

Incipient overtopping discharge $\quad 4,740 \quad \mathrm{ft}^{3} / \mathrm{s}$

Water-surface elevation in bridge opening $\quad 493.4 \quad$ t

Area of flow in bridge opening $\quad 368 \quad \mathbf{f t}^{2}$

Average velocity in bridge opening $\quad 12.9 \quad \mathrm{ft} / \mathrm{s}$

Maximum WSPRO tube velocity at bridge $\quad 17.2 \mathrm{ft} / \mathrm{s}$

Water-surface elevation at Approach section with bridge

Water-surface elevation at Approach section without bridge

497.0

Amount of backwater caused by bridge $\quad 2.0$, t 


\section{Scour Analysis Summary}

\section{Special Conditions or Assumptions Made in Scour Analysis}

Scour depths were computed using the general guidelines described in Hydraulic Engineering Circular 18 (Richardson and Davis, 1995). Scour depths were calculated assuming an infinite depth of erosive material and a homogeneous particle-size distribution. The results of the scour analyses for the 100- and 500-year discharges are presented in tables 1 and 2 and the scour depths are shown graphically in figure 8 .

Contraction scour for the incipient roadway-overtopping discharge was computed by use of the Laursen clear-water contraction scour equation (Richardson and Davis, 1995, p. 32 , equation 20). At this site, the 100- and 500-year discharges resulted in submerged orifice flow. Contraction scour at bridges with orifice flow is best estimated by use of the Chang pressure-flow scour equation (oral communication, J. Sterling Jones, October 4, 1996). Thus, contraction scour for these discharges was computed by use of the Chang equation (Richardson and Davis, 1995, p. 145-146). The streambed armoring depths computed suggest that armoring will not limit the depth of contraction scour.

For comparison, contraction scour for the discharges resulting in orifice flow also was computed by use of the Laursen clear-water contraction scour equation and the Umbrell pressure-flow equation (Richardson and Davis, 1995, p. 144). Results from these computations are presented in appendix F.

Abutment scour for the left abutment was computed by use of the Froehlich equation (Richardson and Davis, 1995, p. 48, equation 28). Variables for the Froehlich equation include the Froude number of the flow approaching the embankments, the length of the embankment blocking flow, and the depth of flow approaching the embankment less any roadway overtopping.

Scour at the right abutment was computed by use of the HIRE equation (Richardson and Davis, 1995, p. 49, equation 29) because the HIRE equation is recommended when the length to depth ratio of the embankment blocking flow exceeds 25 . The variables used by the HIRE abutment-scour equation are defined the same as those defined for the Froehlich abutment-scour equation. 


\section{Scour Results}

Contraction scour:

Main channel

Live-bed scour

Clear-water scour

Depth to armoring

Left overbank

Right overbank

Local scour:

Abutment scour

Left abutment

Right abutment

Pier scour

Pier 1

Pier 2

Pier 3 100-year
discharge 500-year discharge

(Scour depths in feet)
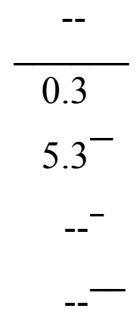

$\longrightarrow$

15.4

$12.0-$

16.5

12.8

11.0

8.6overtopping

Incipient discharge 


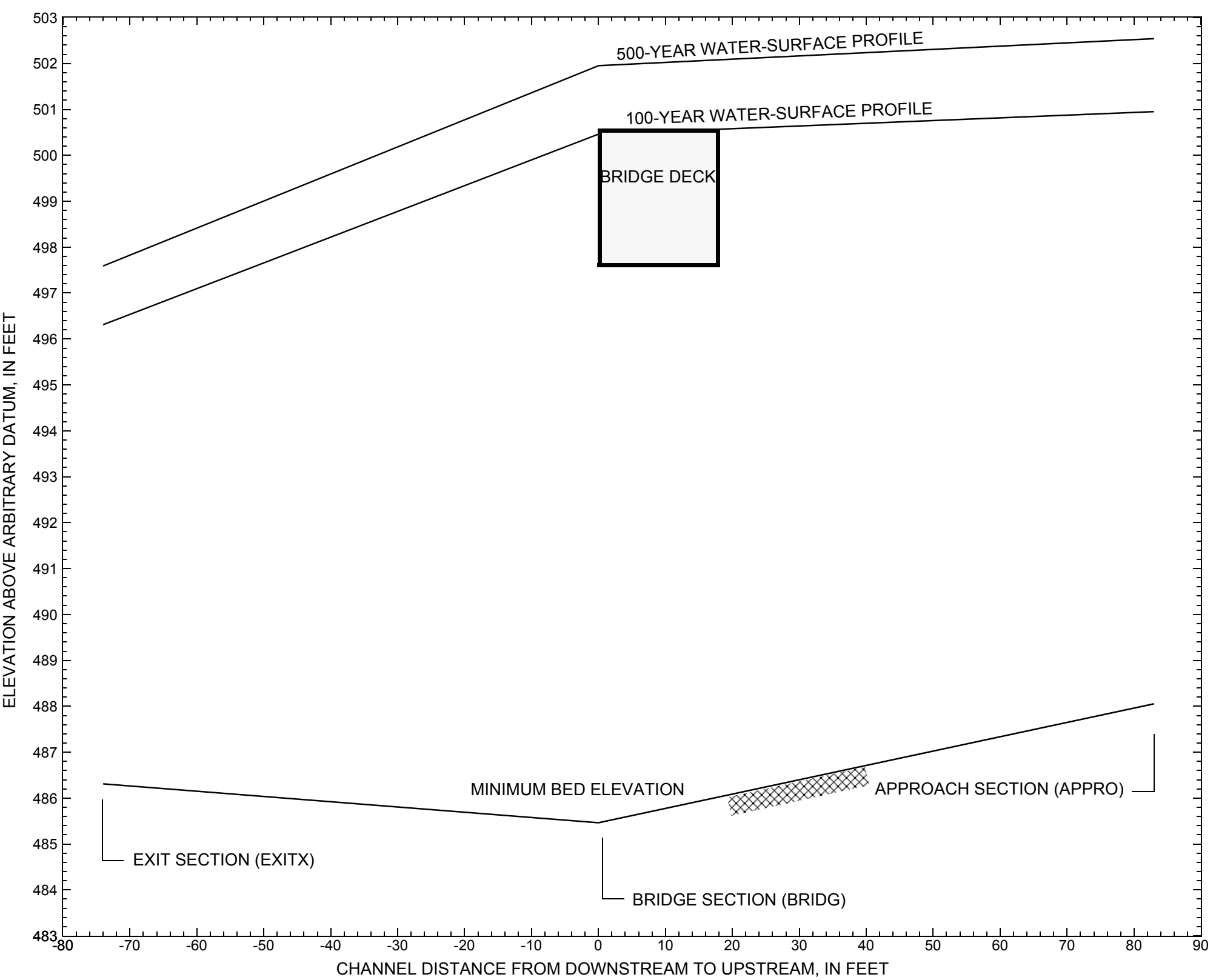

Figure 7. Water-surface profiles for the 100- and 500-year discharges at structure JAMATH00080034 on Town Highway 8, crossing the Winhall River, Jamaica, Vermont. 


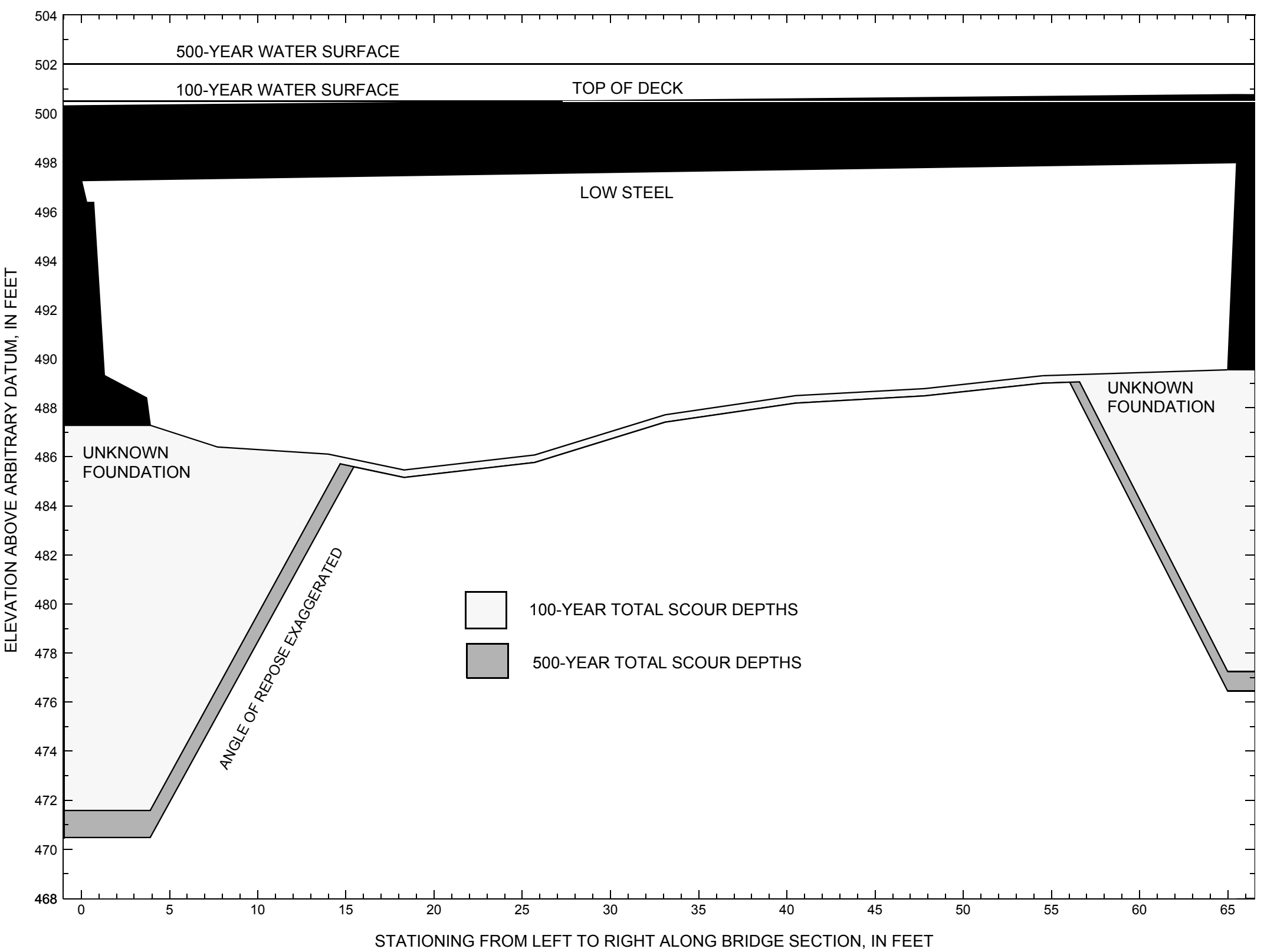

Figure 8. Scour elevations for the 100- and 500-year discharges at structure JAMATH00080034 on Town Highway 8, crossing the Winhall River, Jamaica, Vermont. 


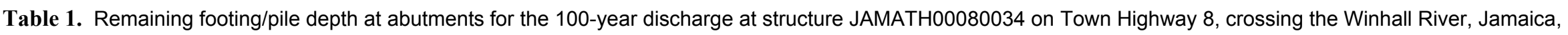
Vermont.

[VTAOT, Vermont Agency of Transportation; --, no data]

\begin{tabular}{|c|c|c|c|c|c|c|c|c|c|c|c|}
\hline Description & Station $^{1}$ & $\begin{array}{l}\text { VTAOT } \\
\text { minimum } \\
\text { low-chord } \\
\text { elevation } \\
\text { (feet) }\end{array}$ & $\begin{array}{l}\text { Surveyed } \\
\text { minimum } \\
\text { low-chord } \\
\text { elevation } \\
\text { (feet) }\end{array}$ & $\begin{array}{c}\text { Bottom of } \\
\text { footing/pile } \\
\text { elevation }{ }^{2} \\
\text { (feet) }\end{array}$ & $\begin{array}{l}\text { Channel } \\
\text { elevation at } \\
\text { abutment/ } \\
\text { pier }^{2} \\
\text { (feet) }\end{array}$ & $\begin{array}{l}\text { Contraction } \\
\text { scour depth } \\
\text { (feet) }\end{array}$ & $\begin{array}{l}\text { Abutment } \\
\text { scour } \\
\text { depth } \\
\text { (feet) }\end{array}$ & $\begin{array}{l}\text { Pier } \\
\text { scour } \\
\text { depth } \\
\text { (feet) }\end{array}$ & $\begin{array}{l}\text { Depth of } \\
\text { total scour } \\
\text { (feet) }\end{array}$ & $\begin{array}{c}\text { Elevation of } \\
\text { scour }^{2} \\
\text { (feet) }\end{array}$ & $\begin{array}{c}\text { Remaining } \\
\text { footing/pile } \\
\text { depth } \\
\text { (feet) }\end{array}$ \\
\hline \multicolumn{12}{|c|}{100 -year discharge is 14,100 cubic-feet per second } \\
\hline Left abutment & 0.0 & -- & 497.3 & -- & 487.3 & 0.3 & 15.4 & -- & 15.7 & 471.6 & -- \\
\hline Right abutment & 65.5 & -- & 498.0 & -- & 489.5 & 0.3 & 12.0 & -- & 12.3 & 477.2 & -- \\
\hline
\end{tabular}

1.Measured along the face of the most constricting side of the bridge.

2.Arbitrary datum for this study.

Table 2. Remaining footing/pile depth at abutments for the 500-year discharge at structure JAMATH00080034 on Town Highway 8, crossing the Winhall River, Jamaica, Vermont.

[VTAOT, Vermont Agency of Transportation; --, no data]

\begin{tabular}{|c|c|c|c|c|c|c|c|c|c|c|c|}
\hline Description & Station $^{1}$ & $\begin{array}{l}\text { VTAOT } \\
\text { minimum } \\
\text { low-chord } \\
\text { elevation } \\
\text { (feet) }\end{array}$ & $\begin{array}{c}\text { Surveyed } \\
\text { minimum } \\
\text { low-chord } \\
\text { elevation } \\
\text { (feet) }\end{array}$ & $\begin{array}{c}\text { Bottom of } \\
\text { footing/pile } \\
\text { elevation } \\
\text { (feet) }\end{array}$ & $\begin{array}{c}\text { Channel } \\
\text { elevation at } \\
\text { abutment/ } \\
\text { pier }^{2} \\
\text { (feet) }\end{array}$ & $\begin{array}{l}\text { Contraction } \\
\text { scour depth } \\
\text { (feet) }\end{array}$ & $\begin{array}{c}\text { Abutment } \\
\text { scour } \\
\text { depth } \\
\text { (feet) }\end{array}$ & $\begin{array}{l}\text { Pier } \\
\text { scour } \\
\text { depth } \\
\text { (feet) }\end{array}$ & $\begin{array}{l}\text { Depth of } \\
\text { total scour } \\
\text { (feet) }\end{array}$ & $\begin{array}{c}\text { Elevation of } \\
\text { scour }^{2} \\
\text { (feet) }\end{array}$ & $\begin{array}{c}\text { Remaining } \\
\text { footing/pile } \\
\text { depth } \\
\text { (feet) }\end{array}$ \\
\hline \multicolumn{12}{|c|}{500 -year discharge is 21,000 cubic-feet per second } \\
\hline Left abutment & 0.0 & -- & 497.3 & -- & 487.3 & 0.3 & 16.5 & -- & 16.8 & 470.5 & -- \\
\hline Right abutment & 65.5 & -- & 498.0 & -- & 489.5 & 0.3 & 12.8 & -- & 13.1 & 476.4 & -- \\
\hline
\end{tabular}

1.Measured along the face of the most constricting side of the bridge.

2.Arbitrary datum for this study. 


\section{SELECTED REFERENCES}

Arcement, G.J., Jr., and Schneider, V.R., 1989, Guide for selecting Manning's roughness coefficients for natural channels and flood plains:

U.S. Geological Survey Water-Supply Paper 2339, 38 p.

Barnes, H.H., Jr., 1967, Roughness characteristics of natural channels: U.S. Geological Survey Water-Supply Paper 1849,213 p.

Benson, M. A., 1962, Factors Influencing the Occurrence of Floods in a Humid Region of Diverse Terrain: U.S. Geological Survey WaterSupply Paper 1580-B, 64 p.

Brown, S.A. and Clyde, E.S., 1989, Design of riprap revetment: Federal Highway Administration Hydraulic Engineering Circular No. 11, Publication FHWA-IP-89-016, 156 p.

Federal Emergency Management Agency, 1988, Flood Insurance Study, Town of Jamaica, Windsor County, Vermont: Washington, D.C., May 17, 1988.

Federal Highway Administration, 1983, Runoff estimates for small watersheds and development of sound design: Federal Highway Administration Report FHWA-RD-77-158.

Federal Highway Administration, 1993, Stream Stability and Scour at Highway Bridges: Participant Workbook: Federal Highway Administration Report FHWA-HI-91-011.

Froehlich, D.C., 1989, Local scour at bridge abutments in Ports, M.A., ed., Hydraulic Engineering--Proceedings of the 1989 National Conference on Hydraulic Engineering: New York, American Society of Civil Engineers, p. 13-18.

Hayes, D.C.,1993, Site selection and collection of bridge-scour data in Delaware, Maryland, and Virginia: U.S. Geological Survey WaterResources Investigation Report 93-4017, 23 p.

Interagency Advisory Committee on Water Data, 1982, Guidelines for determining flood flow frequency: U.S. Geological Survey, Bulletin 17B of the Hydrology Subcommittee, 190 p.

Johnson, C.G. and Tasker, G.D.,1974, Progress report on flood magnitude and frequency of Vermont streams: U.S. Geological Survey OpenFile Report 74-130, 37 p.

Lagasse, P.F., Schall, J.D., Johnson, F., Richardson, E.V., Chang, F., 1995, Stream Stability at Highway Structures: Federal Highway Administration Hydraulic Engineering Circular No. 20, Publication FHWA-IP-90-014, 144 p.

Laursen, E.M., 1960, Scour at bridge crossings: Journal of the Hydraulics Division, American Society of Civil Engineers, v. 86, no. HY2, p. 39-53.

Potter, W. D., 1957a, Peak rates of runoff in the Adirondack, White Mountains, and Maine woods area, Bureau of Public Roads

Potter, W. D., 1957b, Peak rates of runoff in the New England Hill and Lowland area, Bureau of Public Roads

Richardson, E.V. and Davis, S.R., 1995, Evaluating scour at bridges: Federal Highway Administration Hydraulic Engineering Circular No. 18, Publication FHWA-IP-90-017, 204 p.

Richardson, E.V., Simons, D.B., and Julien, P.Y., 1990, Highways in the river environment: Federal Highway Administration Publication FHWA-HI-90-016.

Ritter, D.F., 1984, Process Geomorphology: W.C. Brown Co., Debuque, Iowa, 603 p.

Shearman, J.O., 1990, User's manual for WSPRO--a computer model for water surface profile computations: Federal Highway Administration Publication FHWA-IP-89-027, 187 p.

Shearman, J.O., Kirby, W.H., Schneider, V.R., and Flippo, H.N., 1986, Bridge waterways analysis model; research report: Federal Highway Administration Publication FHWA-RD-86-108, 112 p.

Talbot, A.N., 1887, The determination of water-way for bridges and culverts.

U.S. Geological Survey, 1971, Andover, Vermont 7.5 Minute Series quadrangle map: U.S. Geological Survey Topographic Maps, Scale 1:24,000. 


\section{APPENDIX A: \\ WSPRO INPUT FILE}




\section{WSPRO INPUT FILE}

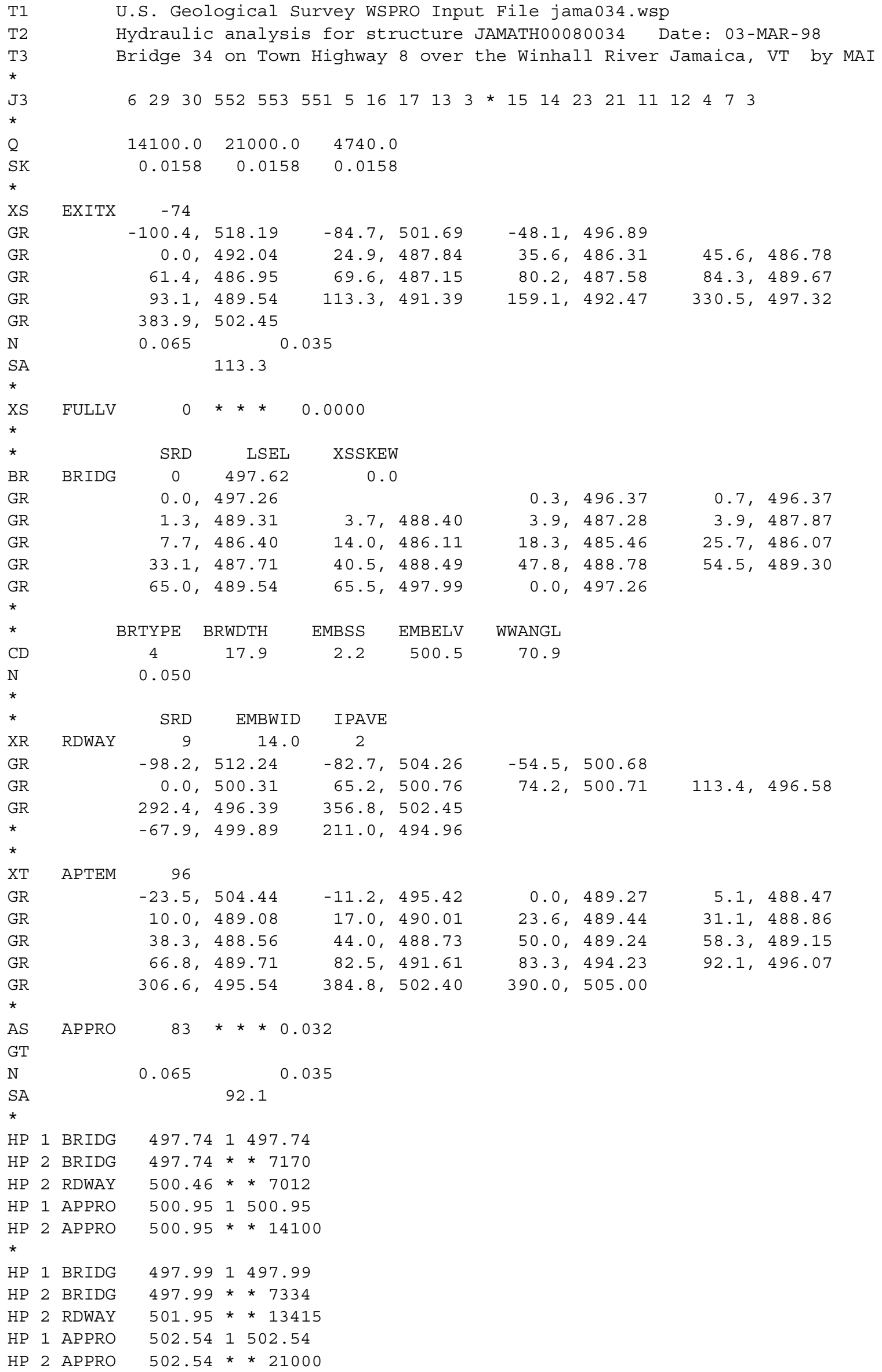




\section{APPENDIX B: \\ WSPRO OUTPUT FILE}




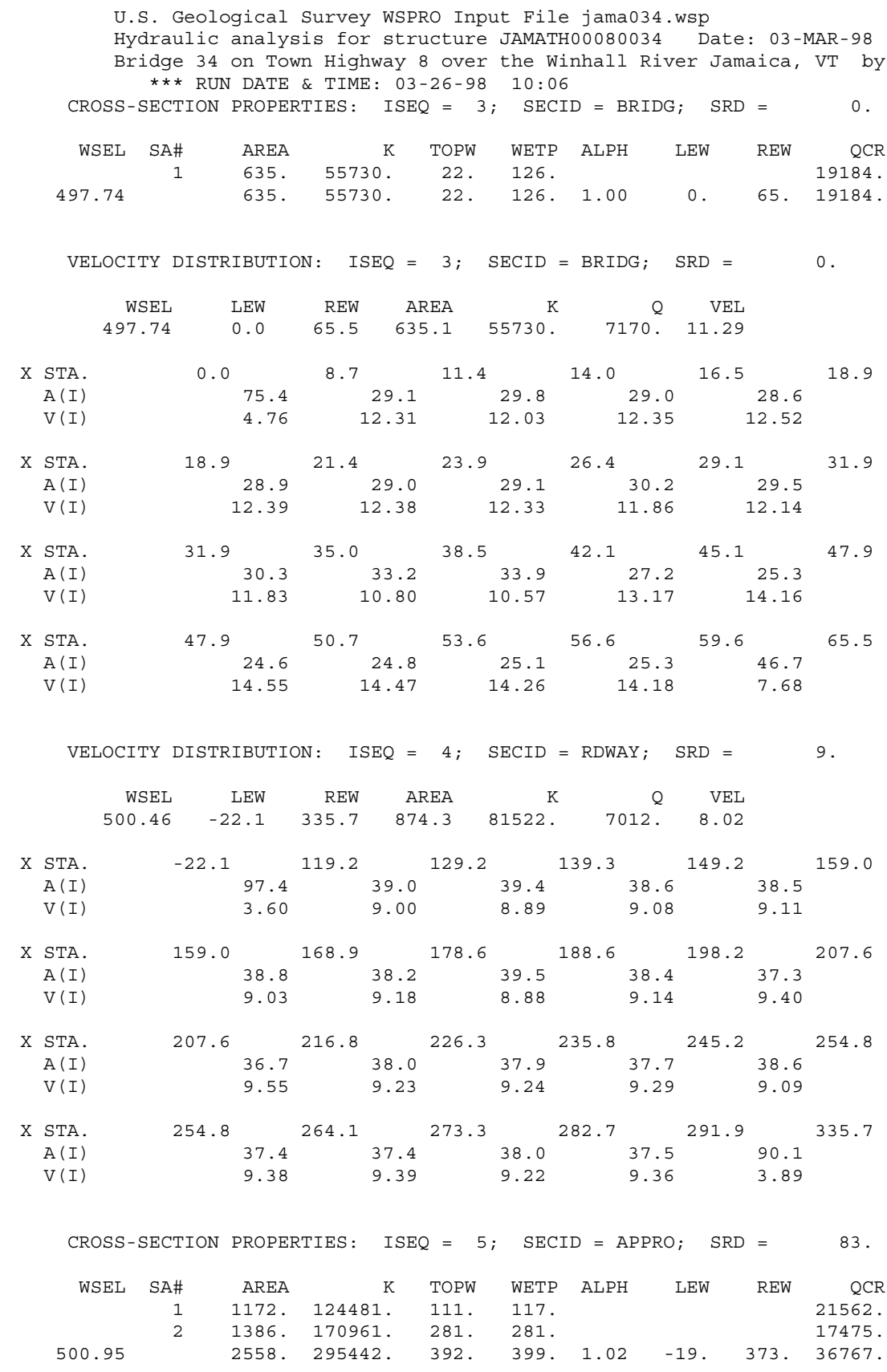

VELOCITY DISTRIBUTION : ISEQ = 5; SECID $=$ APPRO; $\quad$ SRD $=83$.

\begin{tabular}{|c|c|c|c|c|c|c|c|}
\hline & & WSEL & REW & EA & $Q$ & VEL & \\
\hline & & 500.95 & 373.0 & 295442 . & 14100. & 5.51 & \\
\hline $\mathrm{X}$ & STA. & -19.3 & 6.1 & 16.4 & 27.1 & 36.7 & 46.4 \\
\hline & $A(I)$ & 202.3 & 124.2 & 125.3 & 120.3 & 123.2 & \\
\hline & $\mathrm{V}(\mathrm{I})$ & 3.48 & 5.68 & 5.62 & 5.86 & 5.72 & \\
\hline $\mathrm{X}$ & STA. & 46.4 & 56.6 & 67.4 & 80.3 & 104.3 & 125.5 \\
\hline & $A(I)$ & 124.5 & 128.8 & 139.9 & 148.0 & 113.4 & \\
\hline & $V(I)$ & 5.66 & 5.47 & 5.04 & 4.76 & 6.22 & \\
\hline $\mathrm{X}$ & STA. & 125.5 & 146.3 & 167.0 & 187.3 & 207.0 & 226.8 \\
\hline & $A(I)$ & 112.1 & 113.2 & 111.6 & 109.7 & 110.9 & \\
\hline & $V(I)$ & 6.29 & 6.23 & 6.32 & 6.43 & 6.36 & \\
\hline $\mathrm{X}$ & STA. & 226.8 & 246.1 & 265.2 & 283.8 & 302.4 & 373.0 \\
\hline & $A(I)$ & 109.2 & 108.9 & 106.6 & 108.1 & 217.7 & \\
\hline & $V(I)$ & 6.46 & 6.47 & 6.61 & 6.52 & 3.24 & \\
\hline
\end{tabular}


WSPRO OUTPUT FILE (continued)

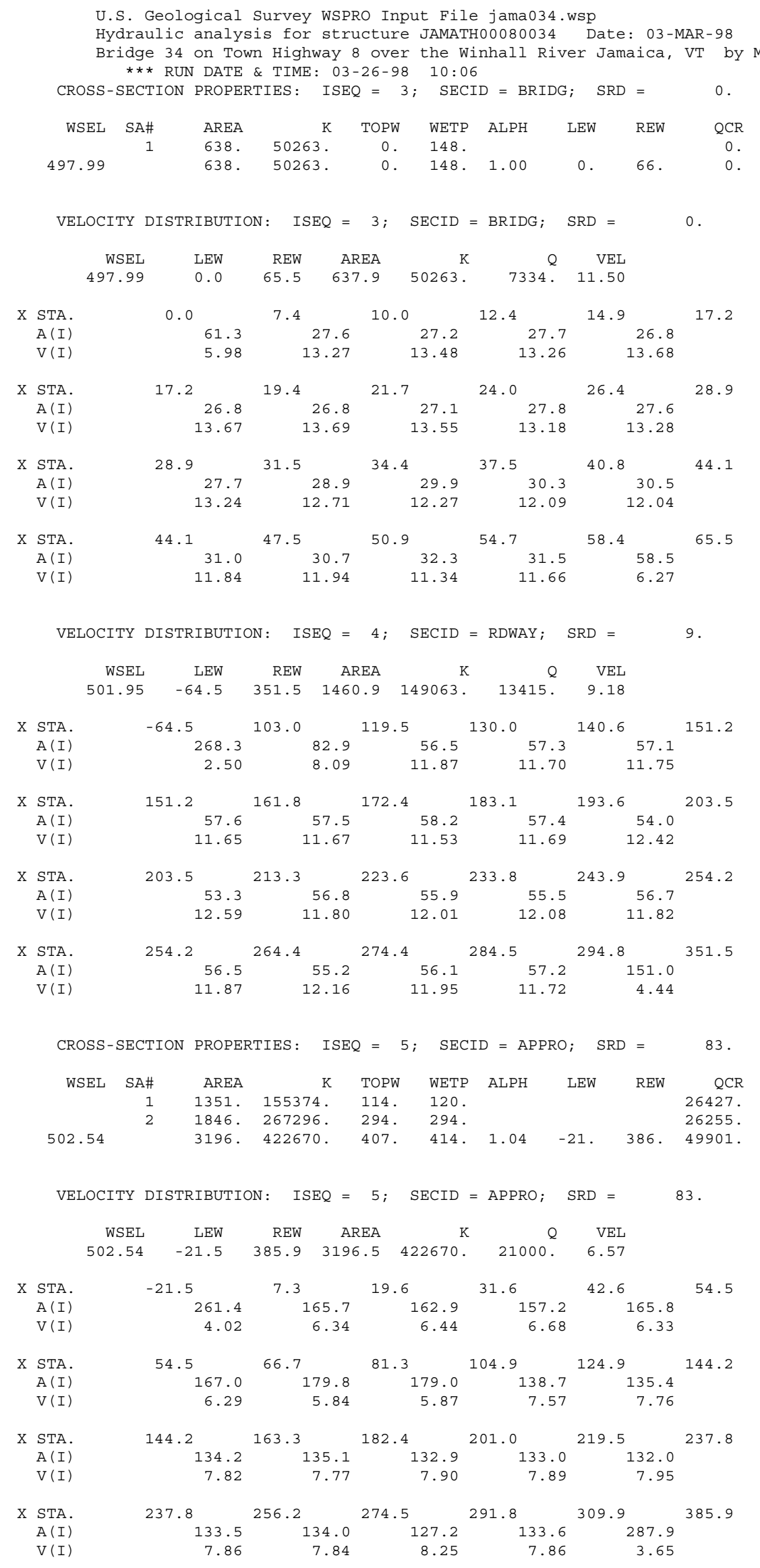


WSPRO OUTPUT FILE (continued)

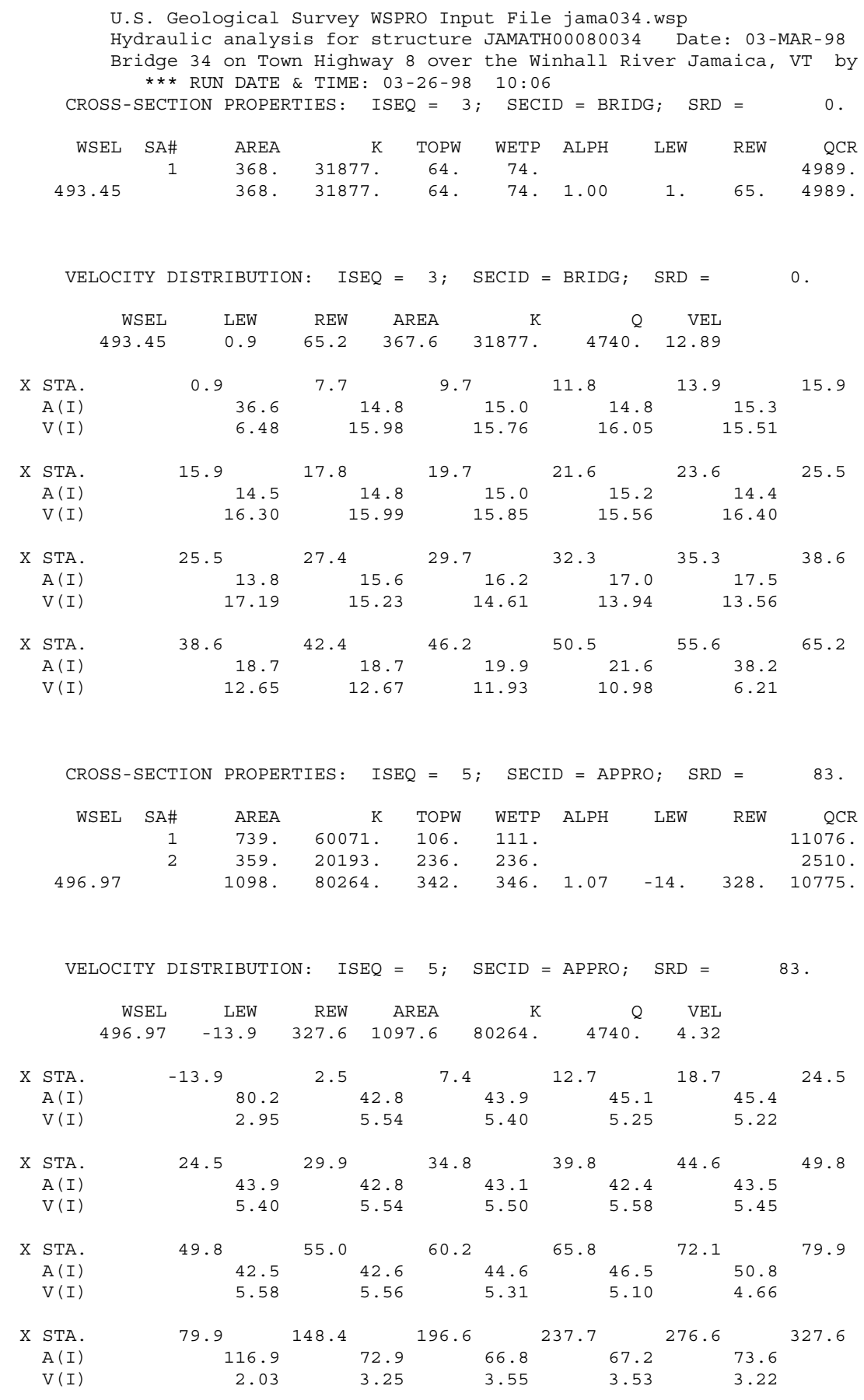


WSPRO OUTPUT FILE (continued)

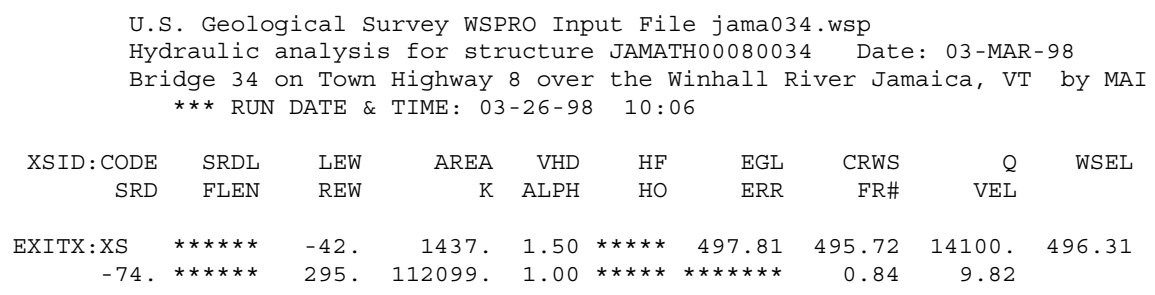

$===135$ CONVEYANCE RATIO OUTSIDE OF RECOMMENDED LIMITS.

"FULLV" KRATIO $=1.56$

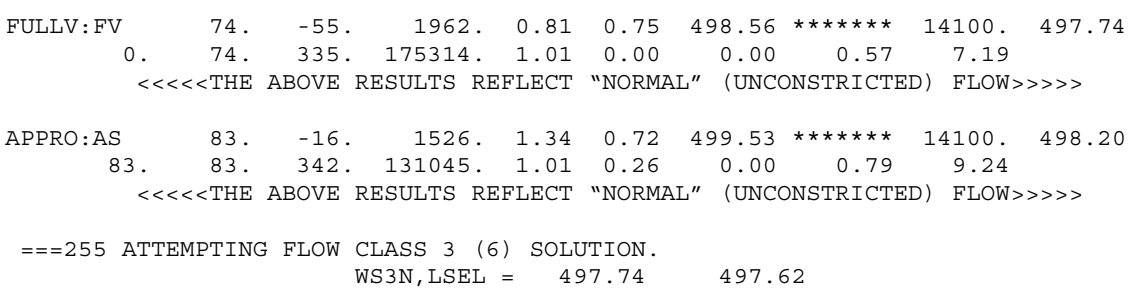

FIRST USER DEFINED TABLE.

\begin{tabular}{|c|c|c|c|c|c|c|c|c|}
\hline XSID : CODE & SRD & LEW & REW & Q & $\mathrm{K}$ & AREA & VEL & WSEL \\
\hline EXITX:XS & -74. & -42 . & 295. & 14100. & 112099. & 1437. & 9.82 & 496.31 \\
\hline FULLV : FV & 0 . & -55. & 335. & 14100. & 175314. & 1962 . & 7.19 & 497.74 \\
\hline BRIDG : BR & 0 . & 0 . & 65. & 7170. & 55620 . & 635. & 11.29 & 497.74 \\
\hline RDWAY : RG & 9. & 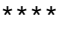 & 102. & 7012 . & 0 . & $* \star \star * \star *$ & 2.00 & 500.46 \\
\hline APPRO : AS & 83. & -19. & 373. & 14100. & 295486 . & 2558 . & 5.51 & 500.95 \\
\hline
\end{tabular}

SECOND USER DEFINED TABLE.

$\begin{array}{lcrrrrrrrr}\text { XSID : CODE } & \text { CRWS } & \text { FR\# } & \text { YMIN } & \text { YMAX } & \text { HF } & \text { HO } & \text { VHD } & \text { EGL } & \text { WSEL } \\ \text { EXITX:XS } & 495.72 & 0.84 & 486.31 & 518.19 * * * * * * * * * * & 1.50 & 497.81 & 496.31 \\ \text { FULLV:FV } & * * * * * * * * & 0.57 & 486.31 & 518.19 & 0.75 & 0.00 & 0.81 & 498.56 & 497.74 \\ \text { BRIDG : BR } & 495.04 & 0.64 & 485.46 & 497.99 * * * * * * * * * * & 1.98 & 499.73 & 497.74 \\ \text { RDWAY:RG } & * * * * * * * * * * * * * * * & 496.39 & 512.24 & 0.16 * * * * * * & 0.48 & 501.27 & 500.46 \\ \text { APPRO:AS } & 497.68 & 0.38 & 488.05 & 504.58 & 0.60 & 0.00 & 0.48 & 501.43 & 500.95\end{array}$


WSPRO OUTPUT FILE (continued)

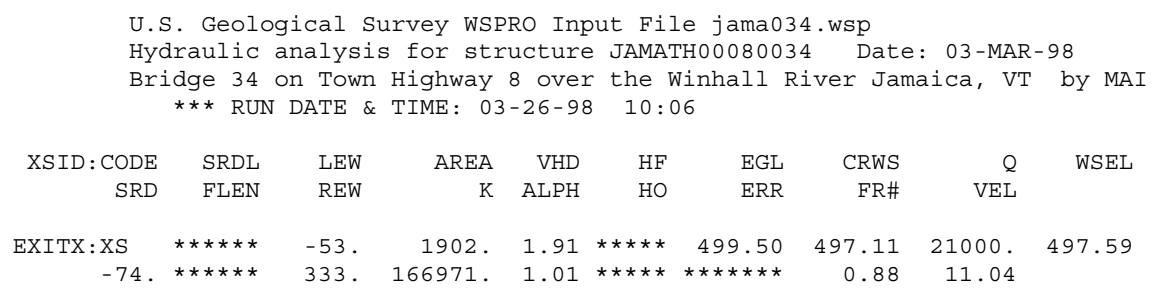

$==135$ CONVEYANCE RATIO OUTSIDE OF RECOMMENDED LIMITS.

"FULLV" KRATIO $=1.55$

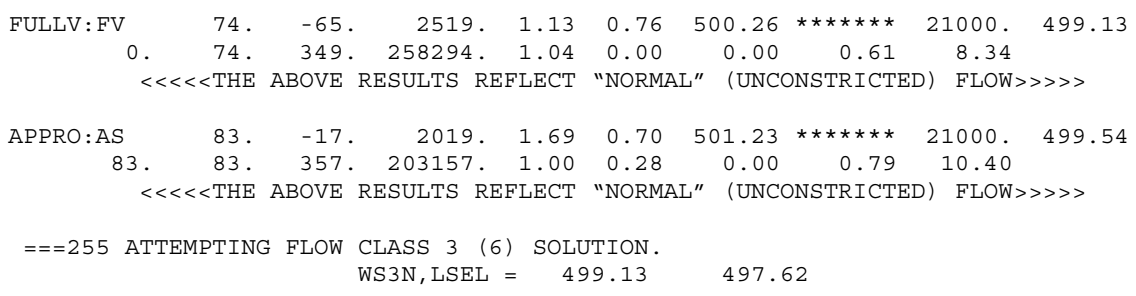

FIRST USER DEFINED TABLE.

\begin{tabular}{|c|c|c|c|c|c|c|c|c|}
\hline XSID : CODE & SRD & LEW & REW & Q & $\mathrm{K}$ & AREA & VEL & WSEL \\
\hline EXITX:XS & -74 . & -53. & 333. & 21000. & 166971. & 1902. & 11.04 & 497.59 \\
\hline FULLV : FV & 0 . & -65. & 349 . & 21000 . & 258294 . & 2519. & 8.34 & 499.13 \\
\hline BRIDG : BR & 0 . & 0 . & 66 . & 7334. & 50263 . & 638. & 11.50 & 497.99 \\
\hline RDWAY : RG & 9. & $* * * *$ & 1094. & 13415. & $\star \star * \star * \star * *$ & $\star \star \star * \star * *$ & 2.00 & 501.95 \\
\hline APPRO : AS & 83. & -21. & 386. & 21000 . & 422547 . & 3196. & 6.57 & 502.54 \\
\hline
\end{tabular}

SECOND USER DEFINED TABLE.

$\begin{array}{lcrrrrrrrr}\text { XSID : CODE } & \text { CRWS } & \text { FR\# } & \text { YMIN } & \text { YMAX } & \text { HF } & \text { HO } & \text { VHD } & \text { EGL } & \text { WSEL } \\ \text { EXITX:XS } & 497.11 & 0.88 & 486.31 & 518.19 * * * * * * * * * * & 1.91 & 499.50 & 497.59 \\ \text { FULLV:FV } & * * * * * * * * & 0.61 & 486.31 & 518.19 & 0.76 & 0.00 & 1.13 & 500.26 & 499.13 \\ \text { BRIDG : BR } & 495.14 & 0.65 & 485.46 & 497.99 * * * * * * * * * * * & 2.06 & 500.05 & 497.99 \\ \text { RDWAY:RG } & * * * * * * * * * * * * * * * * & 496.39 & 512.24 & 0.17 * * * * * * & 0.70 & 503.06 & 501.95 \\ \text { APPRO:AS } & 498.72 & 0.42 & 488.05 & 504.58 & 0.90 & 0.00 & 0.70 & 503.23 & 502.54\end{array}$


WSPRO OUTPUT FILE (continued)

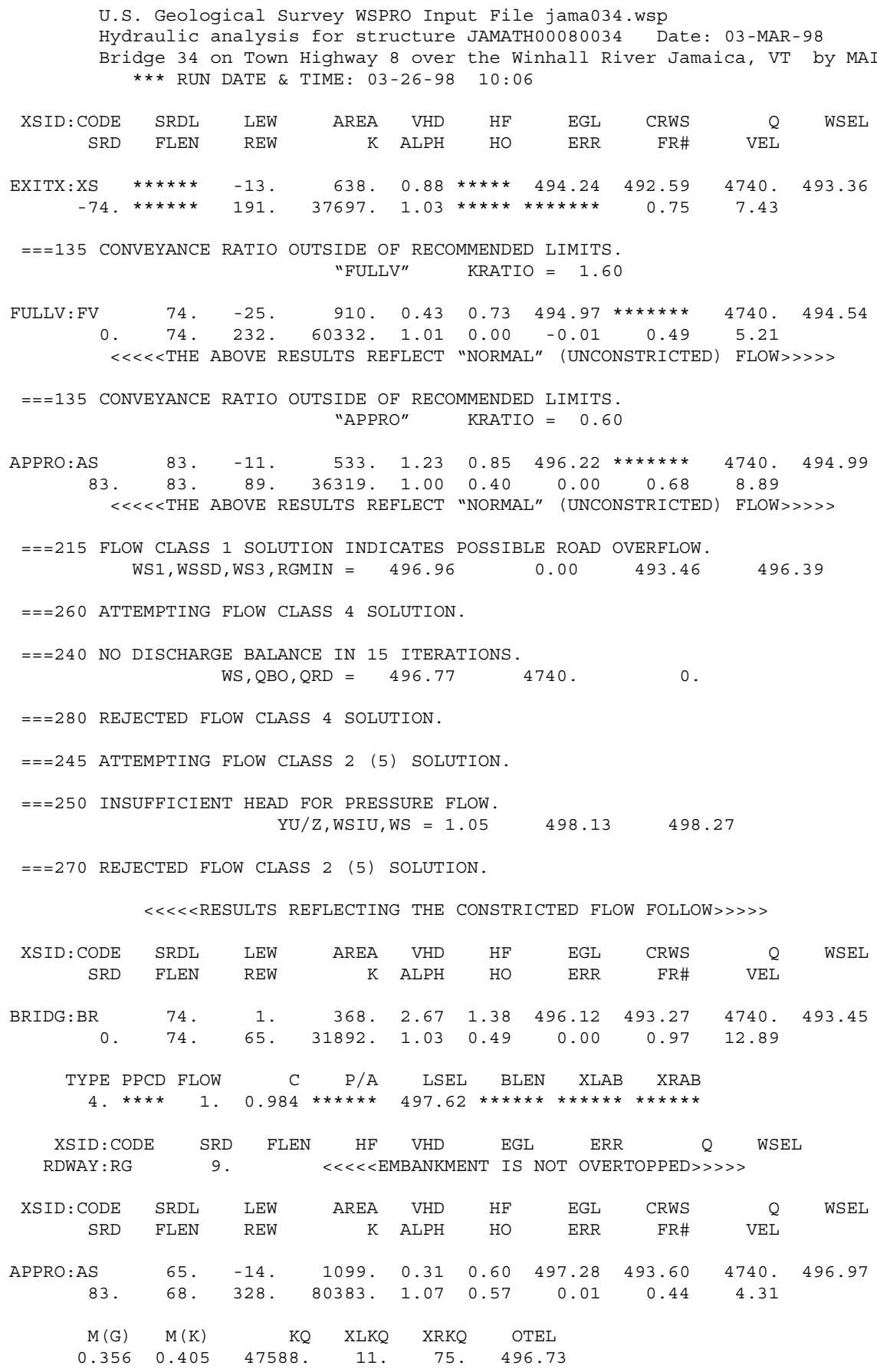

FIRST USER DEFINED TABLE.

\begin{tabular}{|c|c|c|c|c|c|c|c|c|}
\hline XSID : CODE & SRD & LEW & REW & $Q$ & $\mathrm{~K}$ & AREA & VEL & WSEL \\
\hline EXITX:XS & -74 & -13 & 191. & 4740 . & 37697 . & 638. & 7.43 & 493.36 \\
\hline FULLV : FV & 0 & -25 & 232 . & 4740 . & 60332 . & 910. & 5.21 & 494.54 \\
\hline BRIDG : BR & 0 . & 1. & 65 & 4740. & 31892 . & 368. & 12.89 & 493.45 \\
\hline RDWAY : RG & \multicolumn{3}{|c|}{ 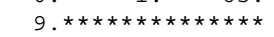 } & 0 & 0 & 0 & \multicolumn{2}{|c|}{$2.00 * * * * * * * *$} \\
\hline APPRO : AS & 83. & -14 & 328. & 4740 . & 80383. & 1099. & 4.31 & 496.97 \\
\hline XSID : CODE & XLKQ & XRKQ & & & & & & \\
\hline APPRO : AS & 11. & 75. & 4758 & & & & & \\
\hline
\end{tabular}

SECOND USER DEFINED TABLE.

$\begin{array}{lcrrrrrrrr}\text { XSID:CODE } & \text { CRWS } & \text { FR\# } & \text { YMIN } & \text { YMAX } & \text { HF } & \text { HO } & \text { VHD } & \text { EGL } & \text { WSEL } \\ \text { EXITX:XS } & 492.59 & 0.75 & 486.31 & 518.19 * * * * * * * * * * * & 0.88 & 494.24 & 493.36 \\ \text { FULLV:FV } & * * * * * * * & 0.49 & 486.31 & 518.19 & 0.73 & 0.00 & 0.43 & 494.97 & 494.54 \\ \text { BRIDG: BR } & 493.27 & 0.97 & 485.46 & 497.99 & 1.38 & 0.49 & 2.67 & 496.12 & 493.45 \\ \text { RDWAY: RG } & * * * * * * * * * * * * * * & 496.39 & 512.24 * * * * * * * * * * & 0.15 & 498.33 * * * * * * * \\ \text { APPRO:AS } & 493.60 & 0.44 & 488.05 & 504.58 & 0.60 & 0.57 & 0.31 & 497.28 & 496.97\end{array}$




\section{APPENDIX C:}

\section{BED-MATERIAL PARTICLE-SIZE DISTRIBUTION}




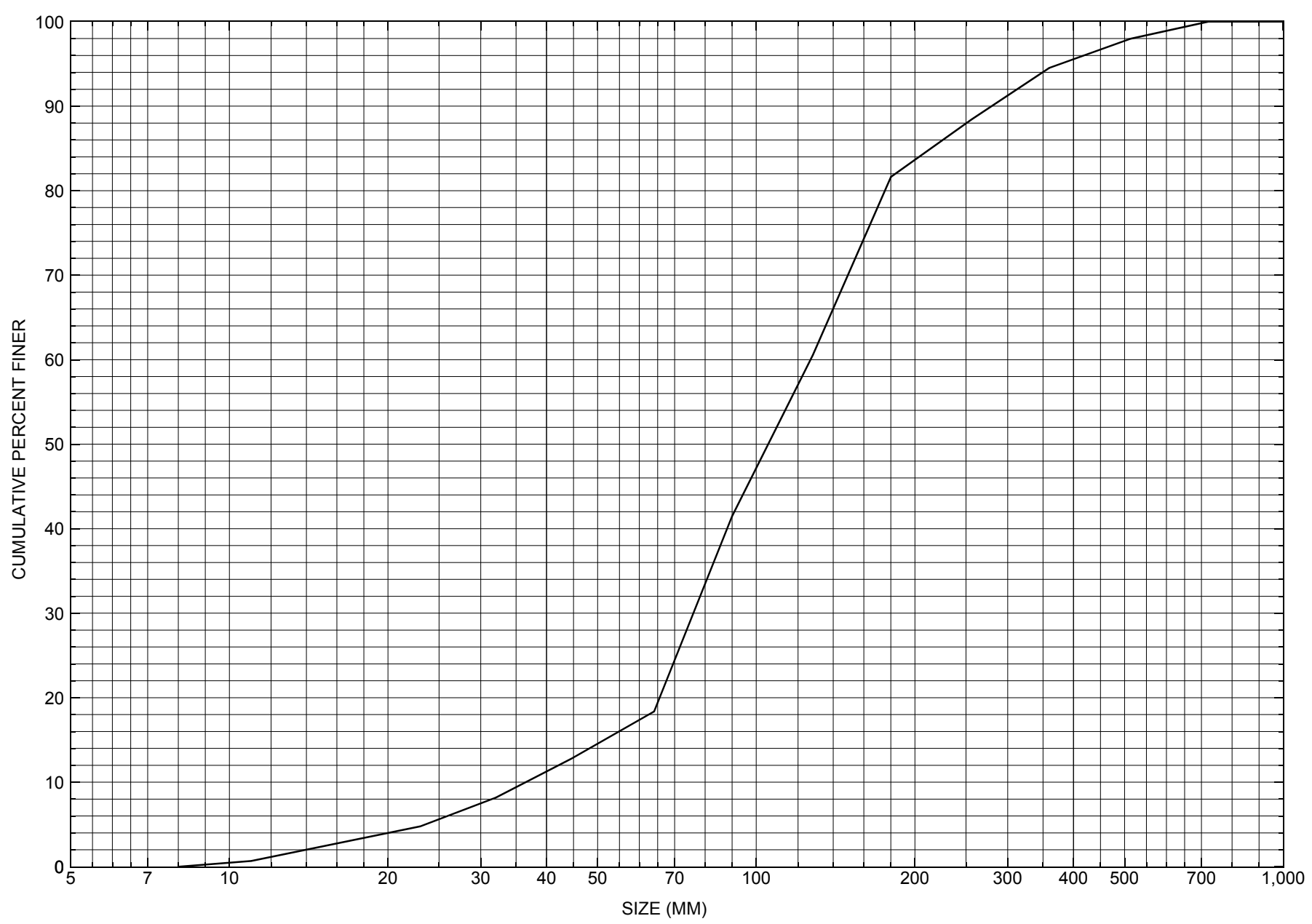

Appendix C. Bed material particle-size distribution for a pebble count in the channel approach of structure JAMATH00080034, in Jamaica, Vermont. 


\section{APPENDIX D: \\ HISTORICAL DATA FORM}




\section{Structure Number JAMATH00080034}

\section{General Location Descriptive}

Data collected by (First Initial, Full last name) $\underline{\text { M. Ivanoff }}$

Date $(M M / D D / Y Y) \_\mathbf{0 4} / \underline{06} / \underline{95}$

Highway District Number (I - 2; nn) $\mathbf{0 2}$

Town (FIPS place code; I - 4; nnnnn) $\mathbf{3 6 1 7 5}$

Waterway (I - 6) Winhall Brook

Route Number TH08

Topographic Map Londonderry

Latitude (I - 16; nnnn.n) $\mathbf{4 3 0 9 4}$
County (FIPS county code; I - 3; nnn)

Mile marker (I - 11; nnn.nnn) $\mathbf{0 0 0 0 0 0}$

Road Name (I - 7): -

Vicinity (I - 9) At the jet. of TH 8 \& TH 4.

Hydrologic Unit Code: $\mathbf{0 1 0 8 0 1 0 7}$

Longitude (i - 17; nnnnn.n) $\mathbf{7 2 4 9 6}$

\section{Select Federal Inventory Codes}

FHWA Structure Number (I - 8) 10130900341309

Maintenance responsibility $(I-21 ; n n) \quad \mathbf{0 3}$

Year built (I - 27; YYYY) 1939

Average daily traffic, ADT (I - 29; nnnnnn) 000050

Year of ADT (I - 30; YY) $\mathbf{9 1}$

Opening skew to Roadway $(I-34 ; n n) \quad \mathbf{0 0}$

Operational status $(I-41 ; X) \underline{\mathbf{A}}$

Structure type (I- 43; nnn) $\mathbf{3 0 2}$

Approach span structure type (I - 44; nnn) $\mathbf{0 0 0}$

Number of spans (I - 45; nnn) $\mathbf{0 0 1}$

Number of approach spans (I - 46; nnnn) $\mathbf{0 0 0 0}$

Comments:

The structural inspection report of $09 / 15 / 93$ indicates the structure is a steel beam type bridge with a timber deck. The right abutment has some minor stains along the bottom. The left abutment has a new concrete facing along the lower portion of wall, and along both wingwalls. This new concrete doesn't have any cracking. There is stone fill around the left abutment. The waterway takes a slight turn through the structure. It has had previous scour problems along the left abutment which have been corrected. The streambed material consists of stone and boulders.

Maximum span length (I - 48; nnnn) $\underline{\mathbf{0 0 7 0}}$

Structure length (I - 49; nnnnnn) $\underline{000074}$

Deck Width (I - 52; nn.n) 140

Channel \& Protection $(I-61 ; n) \underline{7}$

Waterway adequacy $(I-71 ; n) \underline{7}$

Underwater Inspection Frequency $(I-92 B ; X Y Y) \_$N

Year Reconstructed (I - 106) $\mathbf{0 0 0 0}$

Clear span (nnn.n ft)

Vertical clearance from streambed (nnn.n ft) $\underline{\mathbf{1 0 . 0}}$

Waterway of full opening $\left(n n n . n \mathrm{ft}^{2}\right)$ 


\section{Bridge Hydrologic Data}

Is there hydrologic data available? $\underline{\mathbf{N}}$ if No, type ctrl-n $h \quad$ VTAOT Drainage area $\left(m i^{2}\right)$ : -

Terrain character:

Stream character \& type: -

Streambed material:

Discharge Data (cfs):

$$
\begin{aligned}
& Q_{2.33}- \\
& Q_{50}-
\end{aligned}
$$

Record flood date $(M M / D D / Y Y)$ :

Estimated Discharge (cfs): Ice conditions (Heavy, Moderate, Light) : -

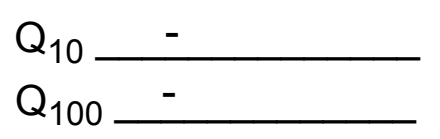

$$
\begin{aligned}
& Q_{25}- \\
& Q_{500}-
\end{aligned}
$$

Water surface elevation $(f t):-$

The stage increases to maximum highwater elevation (Rapidly, Not rapidly):

The stream response is (Flashy, Not flashy):

Describe any significant site conditions upstream or downstream that may influence the stream's stage: -

Watershed storage area (in percent): _ _ \%

The watershed storage area is: - (1-mainly at the headwaters; 2- uniformly distributed; 3-immediatly upstream oi the site)

Water Surface Elevation Estimates for Existing Structure:

\begin{tabular}{|l|l|l|l|l|l|}
\hline Peak discharge frequency & $Q_{2.33}$ & $Q_{10}$ & $Q_{25}$ & $Q_{50}$ & $Q_{100}$ \\
Water surface elevation (ft)) & - & - & - & - & - \\
Velocity (ft/sec) & - & - & - & - & - \\
\hline
\end{tabular}

Long term stream bed changes: -

Is the roadway overtopped below the $\mathrm{Q}_{100}$ ? (Yes, No, Unknown): $\mathbf{U}$ Frequency: Relief Elevation (ft): Discharge over roadway at $Q_{100}\left(f^{3} / \mathrm{sec}\right)$ :

Are there other structures nearby? (Yes, No, Unknown): $\underline{\mathbf{U}}$ Upstream distance (miles): Town: If No or Unknown, type ctrl-n os Highway No. : Structure No. : Year Built:

Clear span (ft): Clear Height $(f t)$ : Full Waterway $\left(f^{2}\right)$ : 
Downstream distance (miles): Town: Year Built:

Highway No. : Structure No. : Structure Type:

Clear span (ft): Clear Height $(f t)$ : Full Waterway $\left(f^{2}\right)$ : -

Comments:

\section{USGS Watershed Data}

Watershed Hydrographic Data

Drainage area $(D A) \underline{45.07} \mathrm{mi}^{2}$

Watershed storage (ST) 1.1

Bridge site elevation 1043

Main channel length 14.92 $\mathrm{ft}$ $\%$ $10 \%$ channel length elevation $\mathrm{mi}$

Lake/pond/swamp area 0.51 $\mathrm{mi}^{2}$

Headwater elevation 3281 $\mathrm{ft}$

Main channel slope (S)

\section{(S)} 110.84 1161 $\mathrm{ft} \quad 85 \%$ channel length elevation $\mathrm{ft}$

Watershed Precipitation Data

Average site precipitation in Average headwater precipitation in

Maximum 2yr-24hr precipitation event $(124,2)$ in

Average seasonal snowfall (Sn) $\mathrm{ft}$ 


\section{Bridge Plan Data}

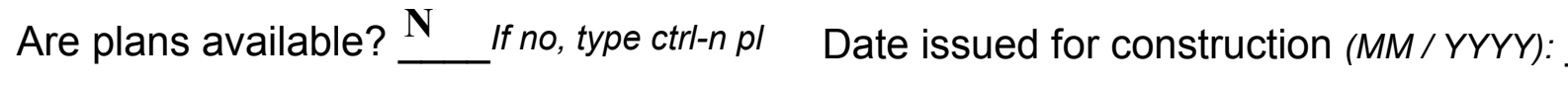

Project Number

Minimum channel bed elevation:

Low superstructure elevation: USLAB DSLAB USRAB DSRAB Benchmark location description:

NO BENCHMARK INFORMATION

Reference Point (MSL, Arbitrary, Other): Datum (NAD27, NAD83, Other):

Foundation Type: 4

If 1: Footing Thickness

If 2: Pile Type: (1-Wood; 2-Ster

(1-

(1-Spreadfooting; 2-Pile; 3- Gravity; 4-Unknown)

Footing bottom elevation:

If 3: Footing bottom elevation:

Foundation Material Type: 3

Briefly describe material at foundation bottom elevation or around piles:

NO FOUNDATION MATERIAL INFORMATION 


\section{Cross-sectional Data}

Is cross-sectional data available? Yes If no, type ctrl-n xs

Source (FEMA, VTAOT, Other)? FEMA

Comments: The station and elevation measurements are in feet.

\begin{tabular}{|l|l|l|l|l|l|l|l|l|l|l|l|}
\hline Station & 170 & 184 & 200 & 202 & 224 & 238 & - & - & - & - & - \\
\hline Feature & LAB & - & - & - & - & RAB & - & - & - & - & - \\
\hline $\begin{array}{l}\text { Low chord } \\
\text { elevation }\end{array}$ & 1060 & 1060 & 1060 & 1060 & 1060 & 1060 & - & - & - & - & - \\
\hline $\begin{array}{l}\text { Bed } \\
\text { elevation }\end{array}$ & 1047.6 & 1048.1 & 1048.2 & 1048.9 & 1049.9 & 1052.8 & - & - & - & - & - \\
\hline $\begin{array}{l}\text { Low chord } \\
\text { to bed }\end{array}$ & 12.4 & 11.9 & 11.8 & 11.1 & 10.1 & 7.2 & - & - & - & - & - \\
\hline Station & - & - & - & - & - & - & - & - & - & - & - \\
\hline Feature & - & - & - & - & - & - & - & - & - & - & - \\
\hline $\begin{array}{l}\text { Low chord } \\
\text { elevation }\end{array}$ & - & - & - & - & - & - & - & - & - & - & - \\
\hline $\begin{array}{l}\text { Bed } \\
\text { elevation }\end{array}$ & - & - & - & - & - & - & - & - & - & - & - \\
\hline $\begin{array}{l}\text { Low chord } \\
\text { to bed }\end{array}$ & - & - & - & - & - & - & - & - & - & - & - \\
\hline
\end{tabular}

Source (FEMA, VTAOT, Other)?

Comments: -

\begin{tabular}{|l|l|l|l|l|l|l|l|l|l|l|l|}
\hline Station & - & - & - & - & - & - & - & - & - & - & - \\
\hline Feature & - & - & - & - & - & - & - & - & - & - & - \\
\hline $\begin{array}{l}\text { Low chord } \\
\text { elevation }\end{array}$ & - & - & - & - & - & - & - & - & - & - & - \\
\hline $\begin{array}{l}\text { Bed } \\
\text { elevation }\end{array}$ & - & - & - & - & - & - & - & - & - & - & - \\
\hline $\begin{array}{l}\text { Low chord } \\
\text { to bed }\end{array}$ & - & - & - & - & - & - & - & - & - & - & - \\
\hline Station & - & - & - & - & - & - & - & - & - & - & - \\
\hline Feature & - & - & - & - & - & - & - & - & - & - & - \\
\hline $\begin{array}{l}\text { Low chord } \\
\text { elevation }\end{array}$ & - & - & - & - & - & - & - & - & - & - & - \\
\hline $\begin{array}{l}\text { Bed } \\
\text { levation }\end{array}$ & - & - & - & - & - & - & - & - & - & - & - \\
\hline $\begin{array}{l}\text { Low chord } \\
\text { to bed }\end{array}$ & - & - & - & - & - & - & - & - & - & - & - \\
\hline
\end{tabular}




\section{APPENDIX E: \\ LEVEL I DATA FORM}


U. S. Geological Survey

Bridge Field Data Collection and Processing Form

Qa/Qc Check by: EW

Date: $10 / 3 / 96$

\section{Structure Number}

JАMATH00080034

\section{A. General Location Descriptive}

1. Data collected by (First Initial, Full last name) $\underline{\mathbf{L}}$. Medalie

2. Highway District Number $\mathbf{0 2}$

Mile marker $\mathbf{0 0 0 0 0 0}$

County Windham (025)

Town Jamaica (36175)

Waterway (I - 6) Winhall Brook

Route Number TH08

Road Name -

Hydrologic Unit Code: $\mathbf{0 1 0 8 0 1 0 7}$

3. Descriptive comments:

This site is located at the junction with TH 4.

\section{B. Bridge Deck Observations}
4. Surface cover... LBUS 6
RBUS 4
LBDS 6
RBDS 4
Overall 6

(2b us,ds,lb,rb: 1- Urban; 2- Suburban; 3- Row crops; 4- Pasture; 5- Shrub- and brushland; 6- Forest; 7- Wetland)
5. Ambient water surface... US 1
UB 1
DS 1
(1- pool; 2- riffle)

6. Bridge structure type 1 (1- single span; 2- multiple span; 3- single arch; 4- multiple arch; 5-cylindrical culvert; 6- box culvert; or 7- other)

7. Bridge length $\mathbf{7 4}$

(feet)

Span length $\mathbf{7 0}$

(feet)

Bridge width 14

(feet)

\section{Road approach to bridge:}
8. LB 2 RB 1
( 0 even, 1- lower, 2- higher)
9. LB_2
RB $\underline{2}$
(1-Paved, 2- Not paved)

10. Embankment slope (run / rise in feet / foot)

$$
\text { US left }
$$

2.6:1

US right

1.7:1

\begin{tabular}{|c|c|c|c|}
\hline \multicolumn{2}{|c|}{ Protection } & \multirow{2}{*}{ 13.Erosion } & 14.Severity \\
\hline 11.Type & 12.Cond. & $\mathbf{0}$ & - \\
\hline $\mathbf{0}$ & - & $\mathbf{0}$ & - \\
\hline $\mathbf{0}$ & - & $\mathbf{2}$ & $\mathbf{1}$ \\
\hline $\mathbf{0}$ & - & $\mathbf{2}$ & $\mathbf{2}$ \\
\hline $\mathbf{0}$ & - & $\mathbf{0}$ & - \\
\hline
\end{tabular}

Bank protection types: 0 - none; 1- $<12$ inches;

2- $<36$ inches; $3-<48$ inches;

4- < 60 inches; 5- wall / artificial levee

Bank protection conditions: 1- good; 2- slumped;

3- eroded; 4- failed

Erosion: 0 - none; 1- channel erosion; 2 -

road wash; 3- both; 4- other

Erosion Severity: 0 - none; 1- slight; 2- moderate; 3- severe

\section{Channel approach to bridge (BF):}

15. Angle of approach: 0

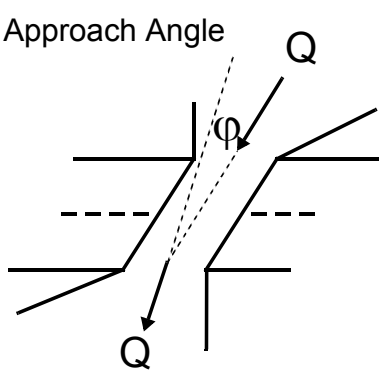

17. Channel impact zone 1 :

Where? LB $(L B, R B)$

Range? $\underline{325}$ feet $\underline{\text { US }}$

Channel impact zone 2:

Where? RB $(L B, R B)$

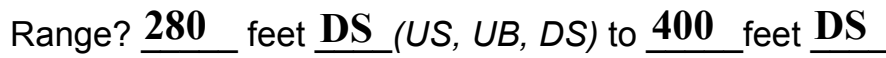

Impact Severity: 0- none to very slight; 1- Slight; 2- Moderate; 3- Severe
16. Bridge skew: $\mathbf{0}$ Bridge Skew Angle

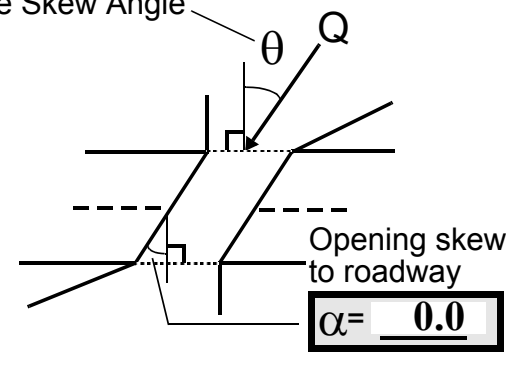

\section{Exist? $\mathbf{Y}(Y$ or $N)$}

Severity 2

(US, UB, DS) to $\mathbf{7 5}$ feet $\underline{\mathbf{U S}}$

Exist? $\mathbf{Y}(Y$ or $N)$

Severity $\underline{2}$ 
18. Bridge Type: 4

1a- Vertical abutments with wingwalls

$1 \mathrm{~b}$ - Vertical abutments without wingwalls

2- Vertical abutments and wingwalls, sloping embankment Wingwalls parallel to abut. face

3- Spill through abutments

4- Sloping embankment, vertical wingwalls and abutments

Wingwall angle less than $90^{\circ}$.

19. Bridge Deck Comments (surface cover variations, measured bridge and span lengths, bridge type variations, approach overflow width, etc.)

4: Along the right bank, upstream and downstream, the surface cover is mostly lawn.

5: The stream is pooled from $35 \mathrm{ft}$ upstream to the upstream bridge face.

7: The measured bridge dimensions are bridge length is $72.6 \mathrm{ft}$; span length is $65.3 \mathrm{ft}$; and bridge width is 14.1 ft.

14: The right bank road wash erosion is moderately severe. The road approach to the bridge is built up on fill and steep slopes exists on either side of it.

\section{Upstream Channel Assessment}

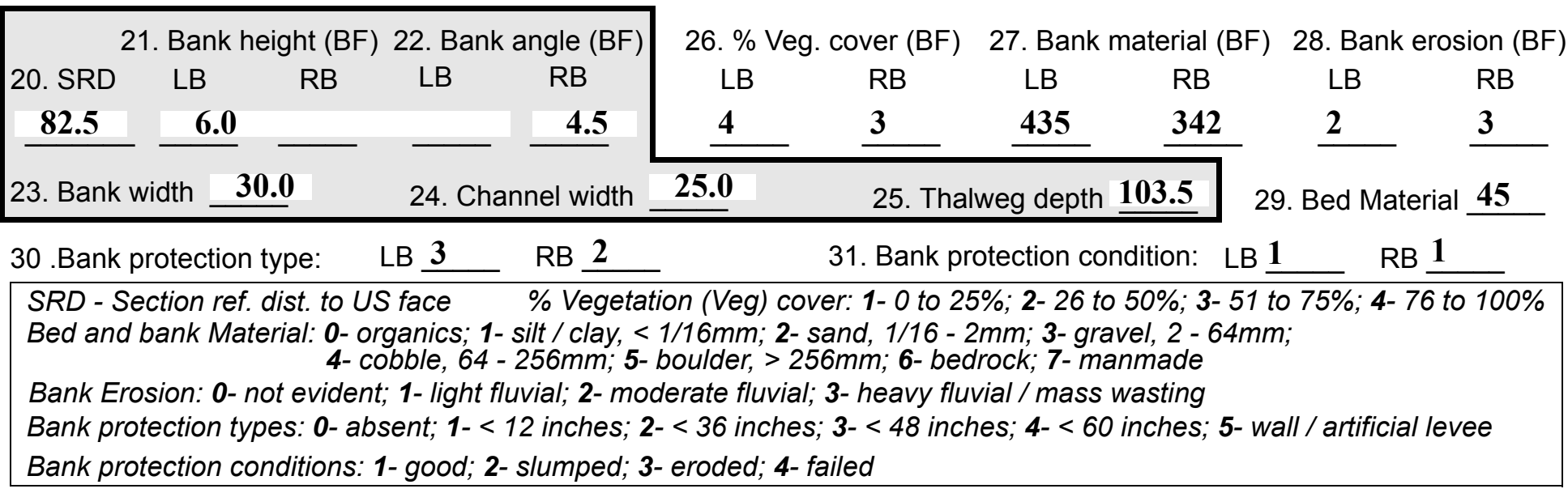

32. Comments (bank material variation, minor inflows, protection extent, etc.):

\#27: The right bank protection extends from the bridge face to $48 \mathrm{ft}$ upstream.

The left bank protection extends from the bridge face to $51 \mathrm{ft}$ upstream. 
36. Point bar extent: $\underline{60}$ feet $\underline{\text { DS }}$ (US, UB) to 110 feet $\underline{\text { DS }}$ (US, UB, DS) positioned $\underline{45} \%$ LB to 90 \%RB

37. Material: 435

38. Point or side bar comments (Circle Point)or Side; Note additional bars, material variation, status, etc.):

A larger point bar exists along the right bank at the sharp bend from $260 \mathrm{ft}$ upstream to at least $500 \mathrm{ft}$ upstream. It consists mostly of cobbles.

39. Is a cut-bank present? $\mathbf{Y}$ ( $Y$ or if $N$ type ctrl-n $c b)$

40. Where? LB (LB or RB)

41. Mid-bank distance: 296

42. Cut bank extent: $\underline{325}$ feet $\underline{\mathbf{U S}}$ (US, UB) to 60 feet $\underline{\mathbf{U S}}$ (US, UB, DS)

43. Bank damage: 3

(1- eroded and/or creep; 2- slip failure; 3- block failure)

44. Cut bank comments (eg. additional cut banks, protection condition, etc.):

45. Is channel scour present? $\mathbf{Y}$ (Y or if $N$ type ctrl-n cs) $\quad$ 46. Mid-scour distance: 168

47. Scour dimensions: Length $\underline{\mathbf{2}}$ Width $\underline{\mathbf{2}}$ Depth : $\underline{\mathbf{1}}$ Position $\underline{\mathbf{0}} \%$ LB to $\underline{\mathbf{1 0}} \%$ RB

48. Scour comments (eg. additional scour areas, local scouring process, etc.):

At $256 \mathrm{ft}$ upstream, there are many local areas of scour around boulders. The area is $15 \mathrm{ft}$ in length, $2 \mathrm{ft}$ wide and $1 \mathrm{ft}$ deep.

49. Are there major confluences? $\mathbf{N}$

51. Confluence 1: Distance Confluence 2: Distance -

54. Confluence comments (eg. confluence name):

NO MAJOR CONFLUENCES

\section{NO MAJOR CONFLUENCES}

( $Y$ or if $N$ type ctrl-n mc)

52. Enters on -

Enters on ( $L B$ or $R B)$ (LB or $R B)$
50. How many? -

53. Type(1- perennial; 2- ephemeral)

Type (1- perennial; 2- ephemeral)

\section{Under Bridge Channel Assessment}

55. Channel restraint (BF)? LB 2

\begin{tabular}{|c|c|}
\hline 56. Height (BF) & 57 Angle (BF) \\
\hline LB $\quad$ RB & LB $\quad$ RB \\
\hline
\end{tabular}

58. Bank width (BF) (1- natural bank; 2- abutment; 3- artificial levee)

Bed and bank Material: 0- organics; 1- silt / clay, < 1/16mm; 2- sand, 1/16 - 2mm; 3- gravel, 2 - 64mm; 4- cobble, 64 - 256mm;

5- boulder, > 256mm; 6- bedrock; 7- manmade
Bank Erosion: 0- not evident; 1- light fluvial; 2- moderate fluvial; 3- heavy fluvial / mass wasting
61. Material (BF)
LB RB
62. Erosion (BF)
$\underline{2} \quad \underline{7}$
7

60. Thalweg depth $\mathbf{9 0 . 0}$
63. Bed Material -

64. Comments (bank material variation, minor inflows, protection extent, etc.):

43 
65. Debris and Ice Is there debris accumulation?

(Yor $N)$ 66. Where? $\mathbf{N}$

(1- Upstream; 2- At bridge; 3- Both)

67. Debris Potential ( 1- Low; 2- Moderate; 3- High)

68. Capture Efficiency 2

(1-Low; 2- Moderate; 3- High)

69. Is there evidence of ice build-up? 2

Ice Blockage Potential $\underline{\mathbf{Y}}$

(1- Low; 2- Moderate; 3- High)

70. Debris and Ice Comments:

2

68: The island and wide point bar in front of the upstream bridge face can block movement of debris and ice.

69: There is significant scrapping of the roots exposed on the right bank cut-bank, $320 \mathrm{ft}$ downstream, that suggests ice damage.

\begin{tabular}{|l|c|c|c|c|c|c|c|c|}
\hline Abutments & $\begin{array}{c}\text { 71. Attack } \\
\angle \text { (BF) }\end{array}$ & $\begin{array}{c}\text { 72. Slope } \angle \\
\text { (Qmax) }\end{array}$ & $\begin{array}{c}\text { 73. Toe } \\
\text { loc. (BF) }\end{array}$ & $\begin{array}{c}\text { 74. Scour } \\
\text { Condition }\end{array}$ & $\begin{array}{c}75 . \text { Scour } \\
\text { depth }\end{array}$ & $\begin{array}{c}\text { 76. Exposure } \\
\text { depth }\end{array}$ & 77. Material & 78. Length \\
\hline LABUT & & $\mathbf{0}$ & $\mathbf{9 0}$ & $\mathbf{2}$ & $\mathbf{2}$ & - & $\mathbf{1}$ & $\mathbf{9 0 . 0}$ \\
\hline RABUT & $\mathbf{1}$ & $\mathbf{0}$ & $\mathbf{9 0}$ & & & $\mathbf{2}$ & $\mathbf{1}$ & $\mathbf{6 5 . 5}$ \\
\hline
\end{tabular}

Pushed: $L B$ or RB

Toe Location (Loc.): 0- even, 1- set back, 2- protrudes

Scour cond.: 0- not evident; 1- evident (comment); 2- footing exposed; 3-undermined footing; 4- piling exposed; 5- settled; 6- failed

Materials: 1- Concrete; 2- Stone masonry or drywall; 3- steel or metal; 4- wood

79. Abutment comments (eg. undermined penetration, unusual scour processes, debris, etc.):

-

1

74: The RABUT has areas of spalling along the bottom, up to 4 inches of concrete has eroded from the face of the abutment.

76: The LABUT footing is exposed with some stone fill on it; the maximum exposure depth along the footing is 1 ft.

80. Wingwalls:

$\begin{array}{llll} & & & \\ \text { Exist? Material? } & \text { Scour } & \text { Scour } & \text { Exposure } \\ \text { Condition? } & \text { depth? } & \text { depth? }\end{array}$

USLWW:

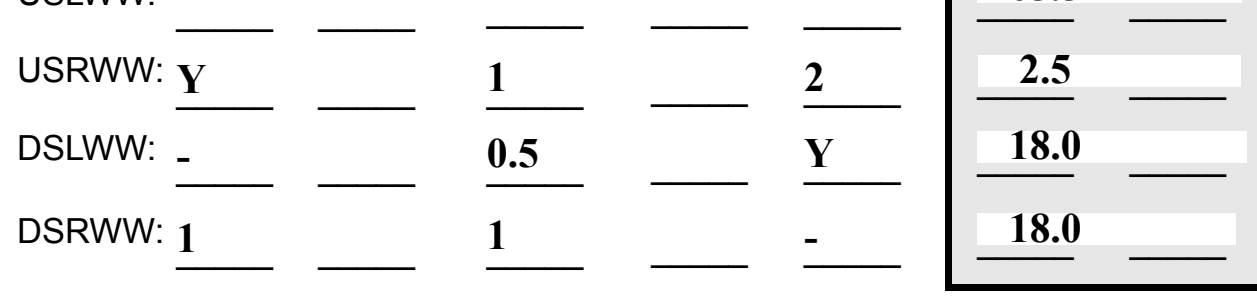

Wingwall materials: 1- Concrete; 2- Stone masonry or drywall; 3- steel or metal; 4- wood

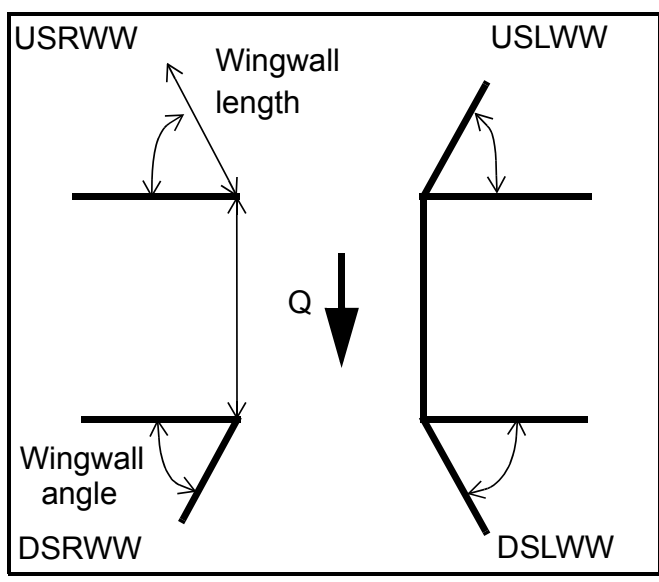

82. Bank / Bridge Protection:

\begin{tabular}{|l|l|l|l|l|l|l|l|c|}
\hline Location & USLWW & USRWW & LABUT & RABUT & LB & RB & DSLWW & DSRWW \\
\hline Type & - & $\mathbf{0}$ & $\mathbf{N}$ & - & $\mathbf{1}$ & $\mathbf{1}$ & $\mathbf{1}$ & $\mathbf{1}$ \\
\hline Condition & $\mathbf{Y}$ & - & - & - & $\mathbf{1}$ & $\mathbf{1}$ & $\mathbf{1}$ & $\mathbf{2}$ \\
\hline Extent & $\mathbf{1}$ & - & - & $\mathbf{2}$ & $\mathbf{2}$ & $\mathbf{4}$ & $\mathbf{2}$ & - \\
\hline
\end{tabular}

Bank / Bridge protection types: 0- absent; 1- < 12 inches; 2- < 36 inches; 3- < 48 inches; 4- < 60 inches; 
83. Wingwall and protection comments (eg. undermined penetration, unusual scour processes, etc.):

-
-
-
-
-
3
1
1
-
-
-

\section{Piers:}

84. Are there piers? \#80 (Y or if $N$ type ctrl-n pr)

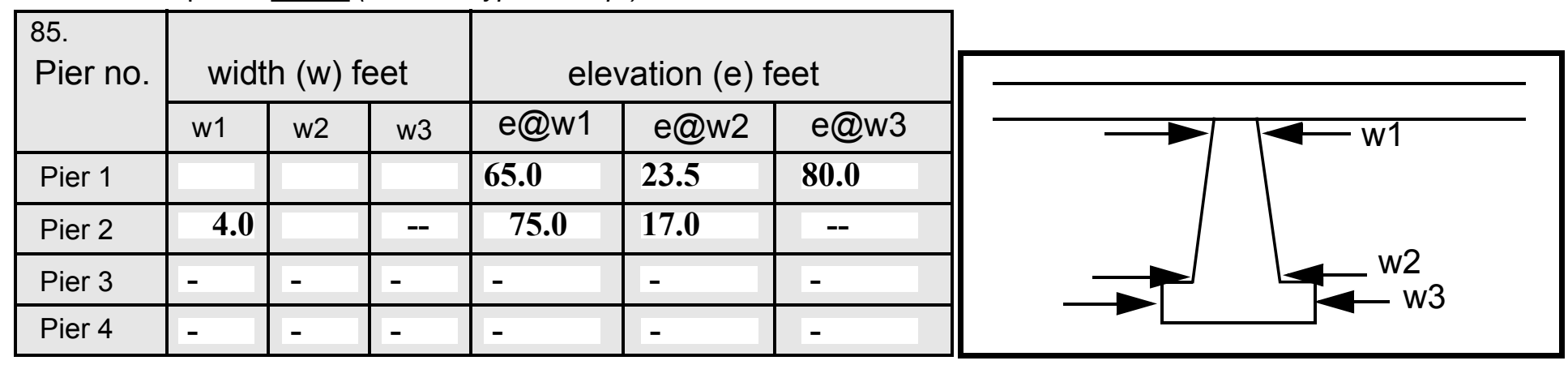

\begin{tabular}{|l|l|l|l|l|}
\hline Level 1 Pier Descr. & \multicolumn{1}{|c|}{1} & \multicolumn{1}{|c|}{2} & \multicolumn{1}{|c|}{3} & \multicolumn{1}{|c|}{4} \\
\hline 86. Location (BF) & The & upstre & the & barely \\
\hline 87. Type & USL & am & dow & scou \\
\hline 88. Material & WW & end. & nstre & red; \\
\hline 89. Shape & is & The & am & a 4 \\
\hline 90. Inclined? & badl & USR & end & inch \\
\hline 91. Attack $\angle$ (BF) & y & WW & for 8 & squa \\
\hline 92. Pushed & spall & foot- & ft. & re \\
\hline 93. Length (feet) & - & - & - & - \\
\hline 94. \# of piles & ed & ing is & The & area \\
\hline 95. Cross-members & and & expo & DSL & at \\
\hline 96. Scour Condition & erod & sed & WW & the \\
\hline 97. Scour depth & ed at & only & is & upst \\
\hline 98. Exposure depth & the & at & just & ream \\
\hline
\end{tabular}

LFP, LTB, LB, MCL, MCM, MCR, RB, RTB, RFP

1- Solid pier, 2- column, 3- bent

1-Wood; 2- concrete; 3- metal; 4- stone

1- Round; 2- Square; 3- Pointed

Y-yes; $N$ - no

$L B$ or $R B$

0- none; 1- laterals; 2- diagonals; 3- both

0- not evident; 1- evident (comment);

2- footing exposed; 3- piling exposed;

4- undermined footing; 5- settled; 6- failed 
99. Pier comments (eg. undermined penetration, protection and protection extent, unusual scour processes, etc.): end.

100.

\section{E. Downstream Channel Assessment}

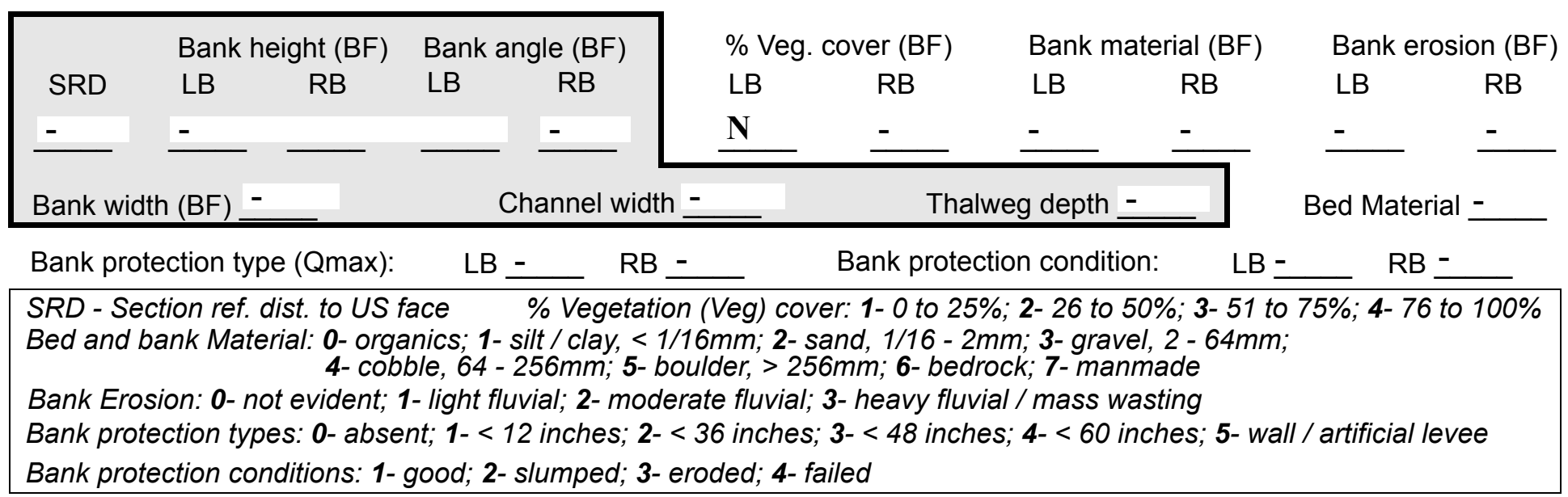

Comments (eg. bank material variation, minor inflows, protection extent, etc.):$$
-
$$$$
-
$$

$-$

$-$

$-$

$-$

$-$

$-$

$-$

-

$-$

$-$

-

$-$

$-$

\section{Is a drop structure present? __ ( $Y$ or $N$, if $N$ type ctrl-n ds) 102. Distance: ___ feet}

103. Drop: __ feet 104. Structure material: __ (1- steel sheet pile; 2- wood pile; 3- concrete; 4- other)

105. Drop structure comments (eg. downstream scour depth):

-

$-$

$-$

-

$-$

$-$ 
106. Point/Side bar present? (Y or $N$. if $N$ type ctrl-n pb)Mid-bar distance:

Mid-bar width: -

Point bar extent: feet -

(US, UB, DS) to feet (US, UB, DS) positioned \%LB to $\%$ RB Material:

Point or side bar comments (Circle Point or Side; note additional bars, material variation, status, etc.):

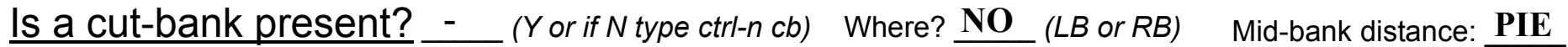

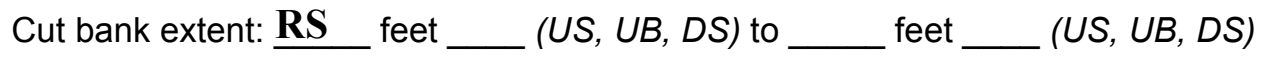

Bank damage: ___ (1- eroded and/or creep; 2- slip failure; 3- block failure)

Cut bank comments (eg. additional cut banks, protection condition, etc.):

Is channel scour present? ( $Y$ or if $N$ type ctrl-n cs) Scour dimensions: Length 2 Width $\underline{324}$ Depth: $\underline{23}$

Mid-scour distance: $\underline{4}$

Scour comments (eg. additional scour areas, local scouring process, etc.): 435

2

0

1

Are there major confluences? - (Y or if $N$ type ctrl-n mc)

Confluence 1: Distance left Enters on ban ( $L B$ or RB)

Enters on tec- (LB or RB)

Positioned $\underline{1} \%$ LB to $\underline{1} \%$ RB

Confluence comments (eg. confluence name):

How many? The

Type $\underline{\mathbf{k}}$ (1- perennial; 2- ephemeral)

Type tion (1- perennial; 2- ephemeral)

extends from the downstream bridge face to $52 \mathrm{ft}$ downstream.

\section{F. Geomorphic Channel Assessment}

107. Stage of reach evolution
1- Constructed

2- Stable

3- Aggraded

4- Degraded

5- Laterally unstable

6- Vertically and laterally unstable 
108. Evolution comments (Channel evolution not considering bridge effects; See HEC-20, Figure 1 for geomorphic descriptors): 


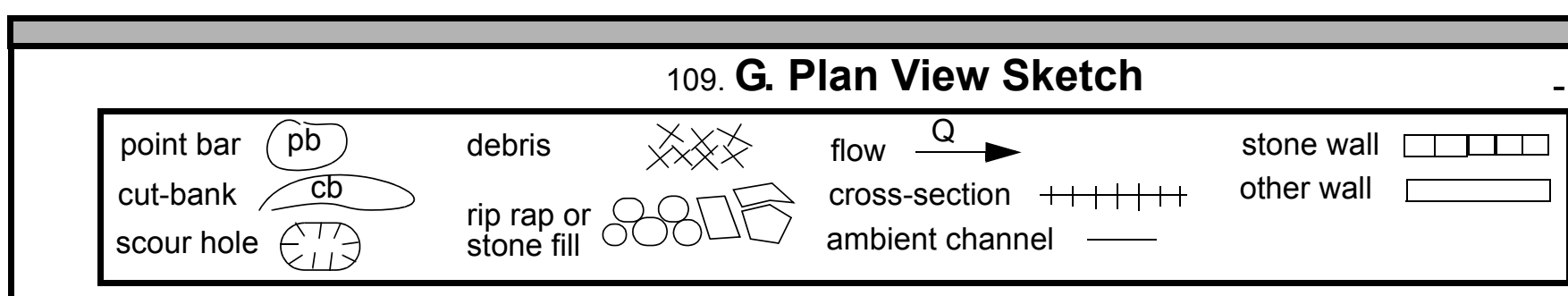


APPENDIX F:

SCOUR COMPUTATIONS 
SCOUR COMPUTATIONS

$\begin{array}{lll}\text { Structure Number: JAMATH00080034 } & \text { Town: Jamaica } \\ \begin{array}{l}\text { Road Number: } \\ \text { Stream: }\end{array} & \text { TH } 8 & \text { County: Windham } \\ & \text { Whinhall River } & \\ \text { Initials MAI } & \text { Date: } 03 / 24 / 98 \text { Checked: RLB }\end{array}$

Analysis of contraction scour, live-bed or clear water?

Critical Velocity of Bed Material (converted to English units) $\mathrm{VC}=11.21 * \mathrm{Y}^{\wedge} 0.1667 * \mathrm{D} 50^{\wedge} 0.33$ with $\mathrm{Ss}=2.65$

(Richardson and Davis, 1995, p. 28, eq. 16)

Approach Section

Characteristic

Total discharge, cfs

Main Channel Area, ft2

Left overbank area, ft2

Right overbank area, ft2

Top width main channel, ft

Top width L overbank, ft

Top width $\mathrm{R}$ overbank, ft

D50 of channel, ft

D50 left overbank, ft

D50 right overbank, ft

Y1, average depth, MC, ft

Y1, average depth, LOB, ft

y1, average depth, ROB, ft

Total conveyance, approach

Conveyance, main channel

Conveyance, LOB

Conveyance, ROB

$100 \mathrm{yr} 500 \mathrm{yr}$ other Q

Percent discrepancy, conveyance

Qm, discharge, MC, Cfs

Q1, discharge, LOB, Cfs

Qr, discharge, ROB, cfs

$14100 \quad 21000 \quad 4740$

$\begin{array}{lll}1172 & 1351 & 739\end{array}$

$\begin{array}{lll}0 & 0 & 0\end{array}$

$\begin{array}{lll}1386 & 1846 & 359\end{array}$

$111 \quad 114 \quad 106$

$0 \quad 0 \quad 0$

$\begin{array}{lll}281 & 294 & 236\end{array}$

$\begin{array}{lll}0.3456 & 0.3456 & 0.3456\end{array}$

- - - - -

$\begin{array}{llll}- & - & - & -\end{array}$

$\mathrm{Vm}$, mean velocity $\mathrm{MC}$, ft/s

$\mathrm{Vl}$, mean velocity, LOB, ft/s

Vr, mean velocity, ROB, ft/s

Vc-m, crit. velocity, $\mathrm{MC}$, ft/s

$\mathrm{VC}-1$, crit. velocity, LOB, ft/s

$\begin{array}{ccc}10.6 & 11.9 & 7.0 \\ \text { ERR } & \text { ERR } & \text { ERR } \\ 4.9 & 6.3 & 1.5\end{array}$

VC-r, crit. velocity, ROB, ft/s

\begin{tabular}{lll}
295442 & 422670 & 80264 \\
124481 & 155374 & 60071 \\
0 & 0 & 0 \\
170961 & 267296 & 20193 \\
0.0000 & 0.0000 & 0.0000 \\
5940.9 & 7719.6 & 3547.5 \\
0.0 & 0.0 & 0.0 \\
8159.1 & 13280.4 & 1192.5 \\
& & \\
5.1 & 5.7 & 4.8 \\
ERR & ERR & ERR \\
5.9 & 7.2 & 3.3 \\
11.7 & 11.9 & \multicolumn{1}{c}{10.9} \\
ERR & ERR & ERR \\
ERR & ERR & ERR
\end{tabular}

Results

Live-bed(1) or Clear-Water(0) Contraction Scour?

$\begin{array}{llll}\text { Main Channel } & 0 & 0 & 0 \\ \text { Left Overbank } & \text { N/A } & \text { N/A } & \text { N/A } \\ \text { Right Overbank } & \text { N/A } & \text { N/A } & \text { N/A }\end{array}$


Clear Water Contraction Scour in MAIN CHANNEL

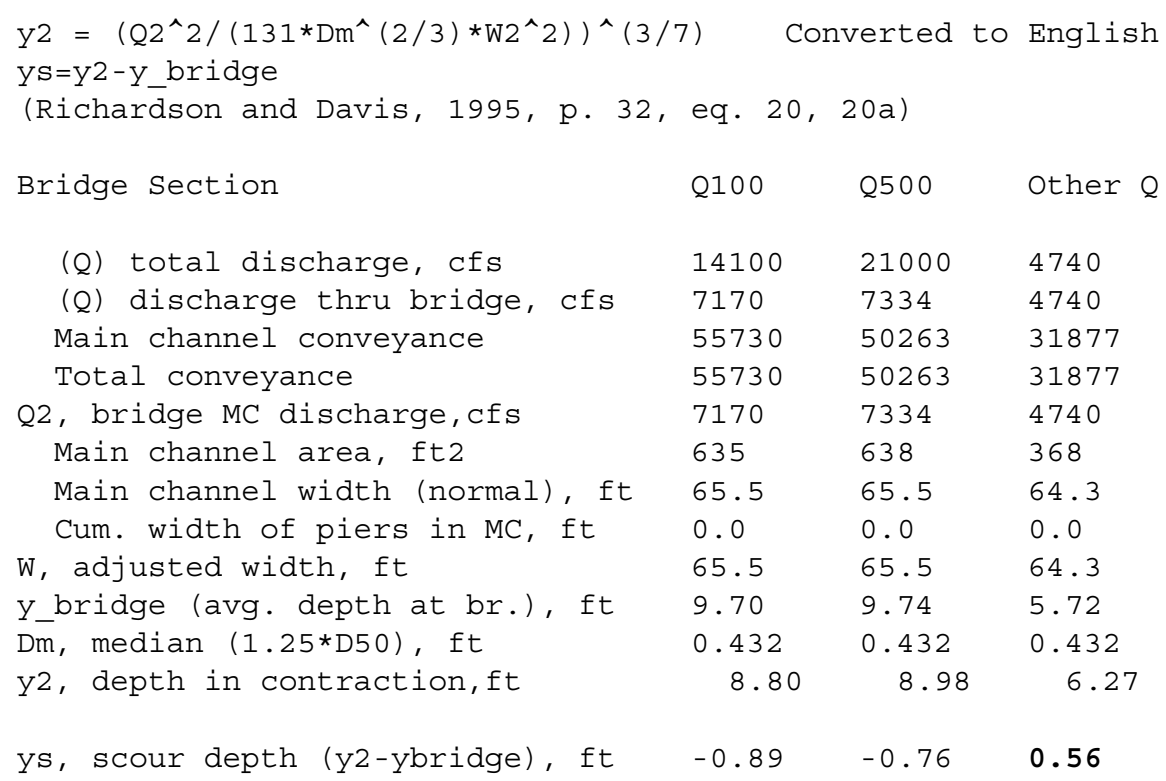

\begin{tabular}{|c|c|c|c|c|}
\hline \multicolumn{5}{|c|}{$\begin{array}{l}\text { Pressure Flow Scour (contraction scour for orifice } f \\
\text { Chang pressure flow equation } \quad \mathrm{Hb}+\mathrm{Ys}=\mathrm{Cq}{ }^{*} \mathrm{qbr} / \mathrm{VC}\end{array}$} \\
\hline \multicolumn{5}{|c|}{$\begin{array}{l}\text { Umbrell pressure flow equation } \\
(\mathrm{Hb}+\mathrm{Ys}) / \mathrm{ya}=1.1021 *[(1-\mathrm{w} / \mathrm{ya}) *(\mathrm{Va} / \mathrm{Vc})]^{\wedge} 0.6031 \\
(\text { Richardson and Davis, 1995, p. 144-146) }\end{array}$} \\
\hline & Q100 & Q500 & OtherQ & \\
\hline Q, total, cfs & 14100 & 21000 & 4740 & \\
\hline Q, thru bridge $M C$, cfs & 7170 & 7334 & 4740 & \\
\hline Vc, critical velocity, ft/s & 11.65 & 11.88 & 10.87 & \\
\hline Va, velocity MC approach, ft/s & 5.07 & 5.71 & 4.80 & \\
\hline Main channel width (normal), ft & 65.5 & 65.5 & 64.3 & \\
\hline Cum. width of piers in MC, ft & 0.0 & 0.0 & 0.0 & \\
\hline w, adjusted width, ft & 65.5 & 65.5 & 64.3 & \\
\hline qbr, unit discharge, ft2/s & 109.5 & 112.0 & 73.7 & \\
\hline Area of full opening, ft2 & 635.1 & 637.9 & 367.6 & \\
\hline $\mathrm{Hb}$, depth of full opening, ft & 9.70 & 9.74 & 5.72 & \\
\hline Fr, Froude number, bridge MC & 0.64 & 0.65 & 0 & \\
\hline Cf, Fr correction factor $(<=1.0)$ & 1.00 & 1.00 & 0.00 & \\
\hline **Area at downstream face, ft2 & $\mathrm{N} / \mathrm{A}$ & $\mathrm{N} / \mathrm{A}$ & $\mathrm{N} / \mathrm{A}$ & \\
\hline **Hb, depth at downstream face, ft & $\mathrm{N} / \mathrm{A}$ & $\mathrm{N} / \mathrm{A}$ & $\mathrm{N} / \mathrm{A}$ & \\
\hline **Fr, Froude number at DS face & $E R R$ & $E R R$ & ERR & \\
\hline$* * \mathrm{Cf}$, for downstream face $(<=1.0)$ & $\mathrm{N} / \mathrm{A}$ & $\mathrm{N} / \mathrm{A}$ & $\mathrm{N} / \mathrm{A}$ & \\
\hline
\end{tabular}




\begin{tabular}{|c|c|c|c|}
\hline Elevation of Low Steel, ft & 497.62 & 497.62 & 497.62 \\
\hline Elevation of Bed, ft & 487.92 & 487.88 & 491.90 \\
\hline Elevation of Approach, ft & 500.95 & 502.54 & 0 \\
\hline Friction loss, approach, ft & 0.6 & 0.9 & 0 \\
\hline Elevation of WS immediately US, ft & 500.35 & 501.64 & 0.00 \\
\hline ya, depth immediately US, ft & 12.43 & 13.76 & -491.90 \\
\hline Mean elevation of deck, ft & 500.53 & 500.53 & 500.53 \\
\hline w, depth of overflow, ft $(>=0)$ & 0.00 & 1.11 & 0.00 \\
\hline Cc, vert contrac correction $(<=1.0)$ & 0.94 & 0.93 & ERR \\
\hline$* * \mathrm{CC}$, for downstream face $(<=1.0)$ & 0.79 & 0.79 & ERR \\
\hline Ys, scour w/Chang equation, ft & 0.31 & 0.34 & $\mathrm{~N} / \mathrm{A}$ \\
\hline Ys, scour w/Umbrell equation, ft & -1.41 & -0.47 & $\mathrm{~N} / \mathrm{A}$ \\
\hline
\end{tabular}

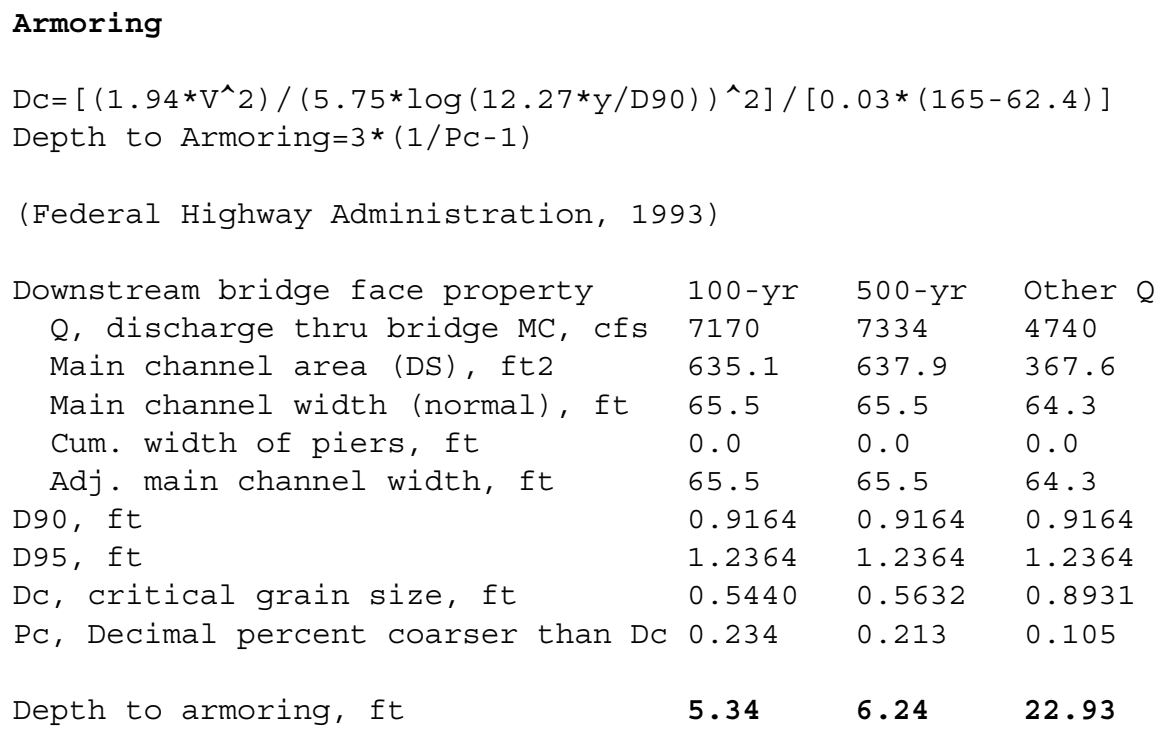

\section{Abutment Scour}

Froehlich's Abutment Scour $\mathrm{Ys} / \mathrm{Y} 1=2.27 * \mathrm{~K} 1 * \mathrm{~K} 2 *\left(\mathrm{a}^{\prime} / \mathrm{Y} 1\right)^{\wedge} 0.43 * \mathrm{Fr} 1^{\wedge} 0.61+1$

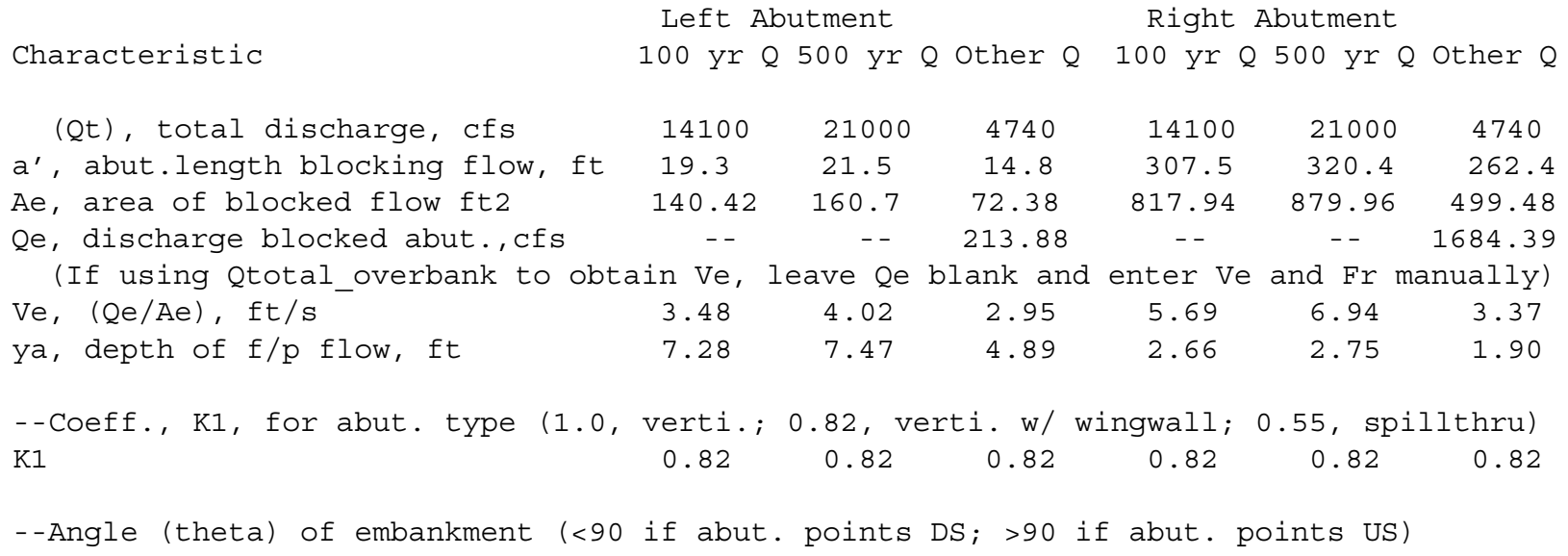




\begin{tabular}{|c|c|c|c|c|c|c|}
\hline theta & 90 & 90 & 90 & 90 & 90 & 90 \\
\hline K2 & 1.00 & 1.00 & 1.00 & 1.00 & 1.00 & 1.00 \\
\hline Fr, froude number $f / p$ flow & 0.218 & 0.235 & 0.235 & 0.435 & 0.474 & 0.431 \\
\hline ys, scour depth, ft & 15.41 & 16.53 & 10.96 & 25.64 & 27.84 & 19.53 \\
\hline \multicolumn{7}{|c|}{$\begin{array}{l}\text { HIRE equation }\left(a^{\prime} / \mathrm{Ya}>25\right) \\
\text { ys }=4 * \mathrm{Fr}^{\wedge} 0.33 * \mathrm{Y} 1 * \mathrm{~K} / 0.55 \\
\text { (Richardson and Davis, 1995, p. 49, eq. 29) }\end{array}$} \\
\hline$a^{\prime}$ (abut length blocked, ft) & 19.3 & 21.5 & 14.8 & 307.5 & 320.4 & 262.4 \\
\hline y1 (depth f/p flow, ft) & 7.28 & 7.47 & 4.89 & 2.66 & 2.75 & 1.90 \\
\hline$a^{\prime} / y 1$ & 2.65 & 2.88 & 3.03 & 115.60 & 116.66 & 137.85 \\
\hline Skew correction (p. 49, fig. 16) & 1.00 & 1.00 & 1.00 & 1.00 & 1.00 & 1.00 \\
\hline Froude no. f/p flow & 0.22 & 0.24 & 0.24 & 0.44 & 0.47 & 0.43 \\
\hline $\begin{array}{c}\text { Ys w/ corr. factor } \mathrm{K} 1 / 0.55: \\
\text { vertical }\end{array}$ & ERR & ERR & ERR & 14.70 & 15.61 & 10.48 \\
\hline vertical w/ $\mathrm{ww}^{\prime} \mathrm{s}$ & ERR & ERR & $\mathrm{ERR}$ & 12.05 & 12.80 & 8.60 \\
\hline spill-through & ERR & ERR & ERR & 8.08 & 8.59 & 5.77 \\
\hline
\end{tabular}

\section{Abutment riprap Sizing}

Isbash Relationship

$\mathrm{D} 50=\mathrm{Y} * \mathrm{~K} * \mathrm{Fr} \wedge 2 /(\mathrm{SS}-1)$ and $\mathrm{D} 50=\mathrm{Y} * \mathrm{~K} *\left(\mathrm{Fr} \mathrm{F}^{\wedge}\right)^{\wedge} 0.14 /(\mathrm{SS}-1)$

(Richardson and Davis, 1995, p112, eq. 81,82)

\begin{tabular}{|c|c|c|c|c|c|c|}
\hline Characteristic & Q100 & Q500 & Other $\mathrm{Q}$ & Q100 & Q500 & Other Q \\
\hline Fr, Froude Number & 0.64 & 0.65 & 0.97 & 0.64 & 0.65 & 0.97 \\
\hline$y$, depth of flow in bridge, ft & 9.70 & 9.74 & 5.72 & 9.70 & 9.74 & 5.72 \\
\hline Median Stone Diameter for riprap & $t:$ left & umenc & & right & abutment & ft \\
\hline Fr $<=0.8$ (vertical abut.) & 2.46 & 2.54 & ERR & 2.46 & 2.54 & $E R R$ \\
\hline Fr>0.8 (vertical abut.) & ERR & ERR & 2.37 & ERR & ERR & 2.37 \\
\hline
\end{tabular}


